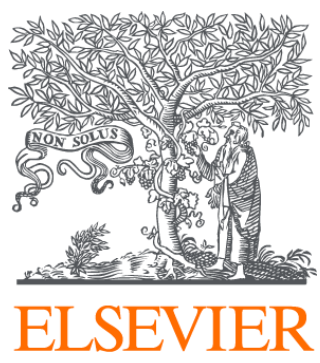

Since January 2020 Elsevier has created a COVID-19 resource centre with free information in English and Mandarin on the novel coronavirus COVID-

19. The COVID-19 resource centre is hosted on Elsevier Connect, the company's public news and information website.

Elsevier hereby grants permission to make all its COVID-19-related research that is available on the COVID-19 resource centre - including this research content - immediately available in PubMed Central and other publicly funded repositories, such as the WHO COVID database with rights for unrestricted research re-use and analyses in any form or by any means with acknowledgement of the original source. These permissions are granted for free by Elsevier for as long as the COVID-19 resource centre remains active. 


\title{
COVID-19 and educational inequality: How school closures affect low- and high-achieving students
}

\author{
Elisabeth Grewenig ${ }^{\text {a }}$, Philipp Lergetporer ${ }^{\text {b,c,d }}$, Katharina Werner ${ }^{\text {c,d,e }}$, \\ Ludger Woessmann ${ }^{\text {c, d, e, f, * , Larissa Zierow }}{ }^{\text {c, d,e }}$ \\ ${ }^{a}$ ZEW - Leibniz Center for European Economic Reserach, Germany \\ ${ }^{\mathrm{b}}$ Technical University of Munich, School of Management, Department of Economics \& Policy, Germany \\ ${ }^{\mathrm{c}}$ ifo Institute, Germany \\ ${ }^{\mathrm{d}}$ CESifo \\ ${ }^{\mathrm{e}}$ University of Munich, Germany \\ ${ }^{\mathrm{f}} I Z A$
}

\section{A R T I C L E I N F O}

\section{JEL codes:}

I24

J62

D30

Keywords:

Educational inequality

COVID-19

Low-achieving students

Home schooling

Distance teaching

\begin{abstract}
A B S T R A C T
In spring 2020, governments around the globe shut down schools to mitigate the spread of the novel coronavirus. We argue that low-achieving students may be particularly affected by the lack of educator support during school closures. We collect detailed time-use information on students before and during the school closures in a survey of 1099 parents in Germany. We find that while students on average reduced their daily learning time of $7.4 \mathrm{~h}$ by about half, the reduction was significantly larger for low-achievers $(4.1 \mathrm{~h})$ than for high-achievers $(3.7 \mathrm{~h})$. Low-achievers disproportionately replaced learning time with detrimental activities such as TV or computer games rather than with activities more conducive to child development. The learning gap was not compensated by parents or schools who provided less support for low-achieving students.
\end{abstract}

\section{Introduction}

To inhibit the spread of the COVID-19 pandemic, many countries closed their schools for several months during the first half of 2020. These closures affected over $90 \%$ of school children (1.5 billion) worldwide (UNESCO, 2020a). A defining feature of school closures is that students do not have the same support of teachers as in traditional in-person classroom teaching. Many have argued that the school closures may increase inequality between children from different family backgrounds (e.g., UNESCO 2020b, European

For helpful comments, we would like to thank the editors Cecile Aubert and Flavio Toxvaerd, two anonymous referees, seminar participants at UCL, the IZA/Jacobs Center Workshop on "Consequences of COVID-19 for Child and Youth Development," the CEPS/EconPol lunch debate, the IMCHILD workshop, the economics of education group of the German Economic Association, the 2021 meeting of the Society of Labor Economists, and the ifo Institute. We are most grateful to Vera Freundl and Franziska Kugler for help in preparing the surveys and to Paul Setzepfand and Michael Möller for excellent research assistance. Financial support by the Leibniz Competition (SAW-2014-ifo-2 and SAW 2019), the German Science Foundation (CRC TRR 190), the NORFACE IMCHILD project, and the NCN-DFG Beethoven Project is gratefully acknowledged. This project was pre-registered before data collection in the list of COVID-19 projects of the European Economic Association.

* Corresponding author.

E-mail addresses: elisabeth.grewenig@zew.de (E. Grewenig), philipp.lergetporer@tum.de (P. Lergetporer), werner.k@ifo.de (K. Werner), woessmann@ifo.de (L. Woessmann), zierow@ifo.de (L. Zierow). 
Commission 2020). But another dimension of inequality that may be particularly relevant for school closures is the one between lowand high-achieving students. Out-of-school learning implies a large amount of self-regulated learning where students must independently acquire and understand the academic content without the support of trained educators. While self-regulated learning may be feasible for high-achieving students during school closures, it may be especially challenging for low-achieving students. In this paper, we provide evidence on how the COVID-19 school closures affected the learning time and other activities of low- and high-achieving students and how parents and schools differentially compensated for the closures.

The COVID-19-related school closures, and the associated temporary discontinuation of traditional in-person teaching, represent an unprecedented disruption of students' educational careers. From an educational production perspective, the school closures induced a sharp decline in what is probably the most important school input factor to produce educational achievement: the support of trained educators. Teachers provide the traditional teaching activities such as explaining new material or providing learning-stimulating feedback. Ample evidence shows that teachers are a key ingredient for students' educational success (e.g., Rivkin et al. 2005). Our data show that direct contact with teachers evaporated during the school closures in Germany, as in many other countries (e.g., Andrew et al. 2020 for England). Instead, students mostly had to embark on self-regulated learning. Since skill formation is a process of dynamic complementarities in the sense that basic skills are necessary to acquire additional skills (e.g., Cunha and Heckman 2007), students with lower initial achievement may lack the knowledge and skill base necessary to generate additional learning gains through self-regulated learning. Consequently, if returns to time invested in independent learning activities are sufficiently low, low-achieving students will spend less time on school-related activities, substituting other activities that are relatively more rewarding to them.

To test this hypothesis, we designed and ran an online survey of 1099 parents of school-aged children in Germany in June 2020. In our detailed time-use data, we carefully elicit how many hours students spent with a range of activities per day both before and during the school closures. We distinguish between (1) school-related activities such as going to school or learning at home; (2) activities generally deemed conducive to child development such as reading, arts, playing music, or doing sports; and (3) activities generally deemed detrimental to child development such as watching TV, playing computer games, or consuming social media. ${ }^{1} \mathrm{The}$ retro- $^{-}$ spective panel structure of our data allows us to investigate how the closures affected the gap in learning time between low- and highachieving students, categorized by their prior school grades. To further investigate the extent to which parents and schools compensated for changes in learning time, we additionally elicited parental involvement in home-schooling activities as well as detailed information on schools' distance-teaching activities. Complementing our analysis of inequality along the achievement dimension, we also analyze the learning-gap change between children from different family backgrounds and by gender.

We find that the school closures had a large negative impact on learning time, particularly for low-achieving students. Overall, students' learning time more than halved from $7.4 \mathrm{~h}$ per day before the closures to $3.6 \mathrm{~h}$ during the closures. While learning time did not differ between low- and high-achieving students before the closures, high-achievers spent a significant $0.5 \mathrm{~h}$ per day more on school-related activities during the school closures than low-achievers. Most of the gap cannot be accounted for by observables such as socioeconomic background or family situation, suggesting that it is genuinely linked to the achievement dimension. Time spent on conducive activities increased only mildly from $2.9 \mathrm{~h}$ before to $3.2 \mathrm{~h}$ during the school closures. Instead, detrimental activities increased from 4.0 to $5.2 \mathrm{~h}$. This increase is more pronounced among low-achievers $(+1.7 \mathrm{~h})$ than high-achievers $(+1.0 \mathrm{~h})$. Taken together, our results imply that the COVID-19 pandemic fostered educational inequality along the achievement dimension.

The COVID-19-induced learning gap between low- and high-achieving students was not compensated by parents' activities. Already before the school closures, parents of low-achievers spent less learning time together with their children than parents of highachievers ( 0.4 versus $0.6 \mathrm{~h}$ per day). The school closures only exacerbated this inequality in parental involvement, as parents of lowachievers increased their time investment in joint learning by less than parents of high-achievers $(+0.5$ versus $+0.6 \mathrm{~h})$.

The activities of schools did not compensate for the learning gap between low- and high-achieving students either. During the school closures, schools and teachers only carried out a fraction of their usual teaching activities via distance teaching. For instance, only $29 \%$ of students had shared lessons for the whole class (e.g., by video call) more than once a week, and only $17 \%$ had individual contact with their teacher more than once a week. This reduction in school activities hit low-achieving students particularly hard: Compared to high-achievers, low-achievers were 13 percentage points less likely to have online lessons and 10 percentage points less likely to have individual teacher contacts more than once a week.

Looking at other dimensions of educational inequality, the COVID-19 school closures did not increase learning-time gaps by parental education, but they affected boys more than girls. While children with a university-educated parent spent significantly more time learning for school than those without a university-educated parent before the school closures, we do not find a significant difference in the reduction in learning time between both groups in response to the closures. However, school support was significantly lower for children without a university-educated parent, which suggests that the school closures may also have amplified socioeconomic inequality in educational achievement. Compared to girls $(-3.5 \mathrm{~h})$, the COVID-19-induced learning disruption was more pronounced for boys $(-4.0 \mathrm{~h})$, who particularly spent more time playing computer games.

\footnotetext{
${ }^{1}$ Time spent on educational activities has been shown to be the most productive input for cognitive skill development among different activities of children (Fiorini and Kaene, 2014). Our further categorization is in line with parents' beliefs about how beneficial the different activities are for their children's development (Section 3.2).
} 
By documenting how the discontinuation of in-person teaching differentially affects low- and high-achieving students, we contribute to the broad literatures on educational production (e.g., Hanushek 2020), skill formation (e.g., Cunha and Heckman 2007), and educational inequality (e.g., Björklund and Salvanes 2011). Our results complement the English time-use study during COVID-19 by Andrew et al. (2020) by investigating inequality along the achievement dimension as well as compensating activities of parents and schools. Our study of a range of substituted conducive and detrimental activities also complements several other contemporaneous studies on how COVID-19-induced school closures affected learning inputs and outcomes such as online learning (e.g., Chetty et al. 2020 for online lesson completion and Bacher-Hicks et al. 2021 for household search for online learning resources in the United States) and standardized tests (e.g., Maldonado and Witte 2020, for Flemish Belgium and Engzell et al. 2021 for the Netherlands), neither of which has a focus on differential effects by the achievement dimension. ${ }^{2}$ Our findings contribute to the rapidly emerging literature on effects of the COVID-19 pandemic on other economic and social outcomes such as labor markets, families, and well-being (e.g., Alon et al. 2020, Chetty et al. 2020 and Fetzer et al. 2020).

The remainder of the paper is structured as follows. Section 2 provides a brief conceptual framework and institutional background on schooling during the COVID-19 pandemic in Germany. Section 3 introduces our data and research design. Section 4 presents results on how the COVID-19 school closures affected learning and other activities of low- and high-achieving students. Section 5 presents results on support structures by parents and schools. Section 6 reports results on differences by parental education background, child gender, and school type as additional dimensions of inequality. Section 7 discusses the findings, and Section 8 concludes.

\section{Conceptual framework and institutional background}

This section provides a conceptual framework (Section 2.1) and institutional background (Section 2.2).

\subsection{School closures in the framework of an education production function}

To frame ideas, we conceptualize the potential effects of school closures on educational inequality in the framework of a standard education production function (e.g., Hanushek 1986, 2020). The production of educational output is expressed as a function $f$ of student ability $A$, family inputs $F$, and school inputs $S$ :

$$
\Delta Y_{i}=f\left(A_{i}, F_{i}, S_{i}\right)
$$

where $\Delta Y_{i}$ is the change in educational output, or learning, of student $i$. While educational output can be conceived generally as the acquisition of skills, $\Delta Y_{i}$ will be approximated by student $i$ 's daily learning time in our empirical application. We will discuss the implications of this approximation for the interpretation of changes in educational inequality below.

In this framework, school closures can be thought of as a reduction in school inputs $S_{i}$. Specifically, a defining feature of school closures is that there is no teacher in the room to help students with their learning. As teachers are probably the most important school input factor for student learning (e.g., Hanushek 1971, Rivkin et al. 2005 and Chetty et al. 2014), students are missing out on key support, and their learning is left more to the discretion of themselves and their families. In standard applications, the education production function is often simplified to be additive in the different inputs. In this case, the effect of a uniform change in school inputs would have the same effect on children from different family backgrounds and different ability levels, thereby leaving educational inequality unaffected.

For school closures to affect educational inequality, either the amount or the production elasticities of the other inputs must depend on the extent of school inputs. ${ }^{3}$ One often hypothesized aspect is that the extent to which families compensate for reduced school inputs may depend on their socioeconomic background (SES). Their child's education may enter the utility function of high-SES parents more strongly, higher education may make them better substitute teachers, and they may have weaker budget constraints. As a consequence, high-SES parents may make sure that their child spends more time learning, may increase their family inputs more strongly, and may be in a better position (either financially or in terms of managing the curricular content) to support their child's learning activities. Formally, provided family inputs may depend on provided school inputs, and high-SES families $(h)$ may react more strongly (in absolute terms) to a decline in school inputs than low-SES families $(l)$ :

$$
\left|\frac{\partial F_{i}}{\partial S_{i}}\right|^{h}>\left|\frac{\partial F_{i}}{\partial S_{i}}\right|^{l}
$$

As high-SES parents compensate more of the lost school inputs than low-SES parents, inequality in educational output will increase in the SES dimension.

\footnotetext{
${ }^{2}$ For additional descriptive evidence on overall learning engagement of students during the school closures in Germany in specific samples, see Anger et al. (2020) and Huber and Helm (2020).

${ }^{3}$ The exposition here assumes that school closures entail the same reduction in school inputs for all students. Another way in which school closures could affect educational inequality is that the decline in effective school inputs may differ for different students, e.g., when high-SES parents are more likely to lobby for or support the implementation of better distance-teaching measures or when schools implement specific measures to reach out to low-SES or low-achieving students. Such mechanisms would give rise to differences in the extent to which schools compensate the lack of in-person teaching by other school inputs in one way or the other.
} 
Here, we emphasize another dimension of inequality, the one between students of different initial achievement. The sharp decline in teacher inputs that defines school closures implies the necessity of self-regulated learning. Outside the school context, students must acquire and understand the academic content more independently without the support of trained educators. Given dynamic complementarities in the skill formation process (e.g., Cunha et al. 2006, Cunha and Heckman 2007 and Cunha et al. 2010), the effectiveness of self-regulated learning will depend on individual students' ability and prior achievement. As a consequence, the presence or absence of school inputs, in particular teachers, will affect the production elasticities of students' own prior achievement. The easiest way to conceptualize this aspect is to depict the extent to which students with different levels of initial achievement $A$ can add to their learning as a negative function of the extent of school inputs:

$$
\frac{\partial Y_{i}}{\partial A_{i}}=g\left(S_{i}\right)
$$

That is, the extent to which high-achieving students acquire larger learning gains compared to low-achieving students will be larger in home schooling than in classroom teaching because high-achieving students have a better skill base for self-regulated learning. As a consequence, school closures are expected to widen educational inequality along the achievement dimension.

To the extent that family SES and students' initial achievement are correlated, the two described mechanisms will exacerbate each other: Socioeconomic differences in family inputs may be one driver for the learning differences between low- and high-achieving students, and differences in initial achievement may be one driver for learning differences between children from low- and highSES backgrounds.

In our empirical application, we proxy for students' educational outcomes by the amount of learning time as captured in a time-use survey. For the very reasons discussed, one may expect children from higher-SES families and higher-achieving students to acquire more skills per hour of learning at home than their counterparts. In this case, the true effects of school closures on the inequality in students' skill acquisition along these two dimensions are likely underestimated by any estimated effects on learning time. The same is true when disadvantaged children are more likely to substitute the reduced learning time by other activities that are otherwise detrimental rather than conducive to child development.

\subsection{Institutional background}

Germany reported its first official COVID-19 case in late January 2020. As infection numbers continued to grow over the following weeks, federal and local governments adopted a broad range of measures to slow down the spread of the virus, such as social-distancing requirements, contact limitations, quarantine after travelling, and closures of shops and restaurants. A first district with a local spike in infections closed its schools on February $28 .^{4}$

On March 13, 2020, the 16 federal states closed all educational institutions throughout Germany (Anger et al., 2020). Only young children (up to age 12) of parents who both work in so-called system-relevant occupations (e.g., health, public safety, public transportation, and groceries) were exempt and could attend emergency services in schools (Notbetreuung). The implementation of emergency services varied across the federal states. In April, the first states began relaxing the requirements for emergency-service attendance, e.g., by expanding the list of system-relevant occupations, including families in which only one parent worked in such an occupation, as well as children of single parents. Children admitted to emergency services were usually not taught regularly, but only supervised.

There was no standardized concept to implement distance teaching during the closures. The state ministers of education also did not formulate specific rules on which subjects should be prioritized during school closures. Instead, decisions regarding the organization of distance-teaching activities were left to the discretion of schools and teachers. Regardless of their specific subjects, all teachers were generally expected to engage in distance teaching. While many schools formally implemented certain distance-teaching activities, in practice teachers' activities were limited and left many students uninstructed (Anger et al., 2020). ${ }^{5}$ Distance-teaching activities were further undermined by the lack of technical equipment in the schools and at students' homes. ${ }^{6}$

\footnotetext{
${ }^{4}$ This section provides an overview of German school policies during the COVID-19 pandemic between March and June 2020. See Appendix B for some general facts about the German school system.

${ }^{5}$ A survey of teachers found that instruction was mostly limited to sending out assignments sheets: Less than half of teachers surveyed provided students with explainer videos, and online instruction via video was provided by fewer than one in five teachers (Bosch Stiftung, 2020).

${ }^{6}$ Technical problems in distance teaching are not surprising in the German context: According to the European Commission (2019), the share of highly digitally equipped schools in Germany is substantially lower than the EU average (e.g., 9\% versus 35\% at ISCED-level 1 institutions; $48 \%$ versus $72 \%$ at ISCED-level 3 institutions). In addition, the teacher survey by Huber et al. (2020) shows that 56\% disagree with the statement that the technical capacity at their school is sufficient for web-based formats.
} 
With regard to student assessments, the states jointly decided that school exit exams should take place despite the pandemic. Most states postponed examinations for high-school diplomas (Abitur) from March to April or May. Unlike final exams, standardized student assessments scheduled for 2020 have been canceled because of the pandemic. Thus, no data are available so far to assess the impact of school closures on students' standardized test scores in Germany. ${ }^{7}$

In late April 2020, education ministers decided to gradually re-open schools, with starting dates and procedures differing across states. Accompanied by political controversies given the continued risk of COVID-19 outbreaks, schools initially re-opened only for graduation classes, and with strict hygiene rules such as compulsory mouth-nose masks and social distancing. ${ }^{8}$ Partial school operations - usually with alternating halves of students per classroom in daily or weekly shifts - were successively expanded to other grade levels during May and June (see Appendix Tables A1 for the timing of school re-openings by state and class type). Ultimately, most students had at least a few weeks of in-person teaching before the summer break. Many students lost up to twelve weeks of in-person classroom teaching as a result of the school closures, equivalent to one third of a school year (Woessmann, 2020). Unfortunately, the education ministries do not provide more specific information about the exact number of weeks during which in-person classes were canceled during the school closures in spring 2020.

After the summer break in August/September 2020, schools opened for all students. However, there were no universal guidelines yet on how to continue school operations through distance teaching in the event of future infection hikes. To the best of our knowledge, we provide the first encompassing quantitative assessment of distance-teaching activities during the school closures in Germany.

\section{Research design and data collection}

Using a survey of parents (Section 3.1), we elicit time-use data on a broad range of students' activities for the periods both before and during the COVID-19-related school closures (Section 3.2), complemented by information on parents' and schools' support activities.

\subsection{The survey}

Our survey of parents of school children was fielded as part of the ifo Education Survey 2020, which provides a representative sample of the German population aged 18 to 69 years. Carried out between June 3 and July 1, 2020, by the survey company Respondi via online access panels, the total sample consisted of 10,338 respondents. From the total sample, we asked all parents of school-aged children $(N=1099)$ to answer a series of questions on their youngest school-aged child before and during the COVID-19-related school closures. ${ }^{9}$ As such, the subsample is a convenience sample of parents with students in all types of primary and secondary schools. However, due to the representativeness of the overall sample, it should provide a very good fit for students in Germany. In fact, comparing parental and child characteristics of our analysis sample to all school children in the representative German Microcensus ${ }^{10}$ shows that the two samples are very similar in terms of observables (Appendix Tables A2), raising confidence in the generalizability of results. $^{11}$

The sociodemographic characteristics of the students and their surveyed parent (Appendix Tables A3) indicate an average student age in the sample of 12.5 years and a rather even gender split. The sample is roughly evenly distributed between students in primary (grades 1-4), upper-track secondary (Gymnasium), and other types of secondary school. Responding parents are also roughly evenly split by gender, and $27 \%$ hold a university degree.

To categorize students as low- or high-achievers, we asked parents about their child's school grades in mathematics and German. ${ }^{12}$ According to their parents, $15.7 \%$ and $12.1 \%$ of students in our sample have grade 1 (best grade) in mathematics and German,

\footnotetext{
${ }^{7}$ For details, see https://www.kmk.org/presse/pressearchiv/mitteilung/detail/News/kmk-pruefungen-finden-wie-geplant-statt.html and https:// www.kmk.org/presse/pressearchiv/mitteilung/detail/News/kmk-iqb-bildungstrend-im-primarbereich-verschoben-teilnahmeverpflichtung-anvera-3-und-vera-8-auf.html [accessed June 2, 2021]. Student achievement tests that were scheduled for 2020 but had to be canceled include the IQB Bildungstrend, VERA 3, and VERA 8 for grades three, four, and eight.

${ }^{8}$ Teachers in particular were skeptical about the re-opening of schools. For example, when the federal state of Hesse announced it would return to normal school operations in all primary schools starting June 22, the teachers' union Gewerkschaft Erziehung und Wissenschaft (GEW) called this decision "unreasonable" (see https://www.gew-hessen.de/bildung/schule-fachgruppen/grundschulen/details/regelbetrieb-fuer-hessischegrundschulen-ab-22-juni0 [accessed June 16, 2021]). Similarly, the German Teachers' Association repeatedly warned against opening schools too quickly (see https://www.lehrerverband.de/warnung-schuloeffnungen [accessed June 16, 2021]).

${ }^{9}$ The parent questions were quite detailed and therefore mentally taxing and time consuming. To minimize the risk that survey fatigue undermines data quality, parents with more than one child were only asked about their youngest school-aged child. Studying the youngest child helps to focus on the challenges of self-regulated learning (which are arguably greater for younger children) and on those whose returns to educational investments tend to be highest (e.g., Cunha et al. 2006).

${ }^{10}$ Research Data Centres of the Federal Statistical Office and the statistical offices of the Länder, Microcensus, census year 2015.

${ }^{11}$ Cases where parents reported that the child had zero hours of schooling on a typical weekday before Corona were excluded from the analysis sample as they cannot be identified as students.

12 The question was worded as follows: "What grades does your youngest child receive in the main subjects (mathematics and German) most frequently?" Respondents reported a separate grade for mathematics and German on the German grade scale (from $1=$ "very good" to $6=$ "failed").
} 
respectively, 34.6 and $41.3 \%$ grade $2,26.4$ and $28.9 \%$ grade $3,10.4$ and $6.2 \%$ grade 4 , and 2.3 and $0.6 \%$ grade $5 .{ }^{13}$ Computing the median of the average grade in the two subjects separately for the three school types, we classify students at or above this median as high-achievers (55.5\%) and those below the median as low-achievers (44.5\%). ${ }^{14}$ Thus, our achievement measure captures children's previous educational performance relative to other children in the same school type.

A regression of a high-achiever indicator on sociodemographic characteristics (column 2 of Appendix Tables A3) indicates few significant observable differences between low- and high-achieving students, with the exceptions that high-achievers are more likely to come from high-income households, have the parent working in home office during Corona, and be younger. Child gender, family status, and parent's work hours do not significantly predict better student grades. We control for these background variables in our regression analysis. ${ }^{15}$

\subsection{Elicitation of time-use information before and during COVID-19}

The core of our analysis is detailed time-use data on students' activities for the period of the COVID-19-related school closures. To be able to investigate whether any differences between low- and high-achieving students already existed before the closures or whether they emerged with the closures, we also elicited the same time-use battery retrospectively for the time before the school closures.

Inspired by the time-use module in the mother-child questionnaire of the German Socio-Economic Panel Study (Schröder et al., 2013), we carefully designed the time-use battery to capture relevant activities that students engaged in before and during the school closures. Parents had to specify how many hours (rounded to the nearest half hour) their child spent during a typical workday on each of the following activities: ${ }^{16} 1$. School attendance; 2 . Learning for school; 3 . Reading or being read to; 4 . Playing music and creative work; 5. Physical exercise; 6. Watching TV; 7. Gaming on computer or smartphone; 8. Social media; 9. Online media; and 10. Time-out (e.g., relaxing). We also provided an open field to specify "Another activity." 17 To be able to study whether and how parents adapted their home-schooling activities vis-à-vis the school closures, we also elicited how much time parents spent together with their child on the respective activities.

For our analysis, we group the activities into three categories: school-related activities (activities 1 and 2), other activities generally deemed conducive to child development (activities 3-5), and activities generally deemed detrimental (activities 6-9). Our categorization is reflected in parents' beliefs about how beneficial each activity is for their child's development, which we elicited after the time-use batteries. Almost all parents consider the two school-related activities (97 and 93\%) and the conducive activities (82-95\%) beneficial (Appendix Tables A4). In contrast, only 22-34\% think that the different detrimental activities are beneficial. Importantly, these assessments do not differ substantially between parents of low- and high-achieving students, implying that any difference in time use cannot be assigned to different beliefs about the activities' developmental effects.

Complementing our time-use data, we also elicited parents' assessment of how the school closures affected their family and learning environment at home, as well as information on the distance-teaching activities undertaken by schools. The five questionnaire items on the home environment capture topics such as how the family coped with the situation, whether it was a psychological burden for the child and the parents, and an overall assessment of the child's home learning environment (see notes to Appendix Tables A7 for question wordings). Schools' distance-teaching activities during school closures were elicited by seven questionnaire items on activities such as shared remote lessons, individual teacher contacts, use of educational videos or software, and providing work sheets (see notes to Table 4 for question wordings).

The survey-based, partially retrospective elicitation of information about children from their parents raises issues of validity and interpretation that we will discuss in Section 7 below. There, we also discuss evidence that several patterns in our data are consistent with alternative data sources, which raises confidence in the validity of our main findings.

\footnotetext{
${ }^{13}$ Reassuringly, the grade distribution in our sample is similar to the distribution in the youth questionnaire of the 2018 wave of the German SocioEconomic Panel Study (GSOEP). Detailed results are available upon request.

${ }^{14}$ Because of the rather coarse grading in primary school (33\% of students have the median average grade of 2.0), a relatively large fraction of primary-school students (64\%) falls into the category of at-or-above median grades, compared to 51 and 53 percent of upper-track and other secondary-school students, respectively. 116 students (10.6\%) had to be excluded from this sub-group analysis because they do not receive numerical grades. Most of them (106) are in primary school, where children usually do not receive numerical grades in the early grade levels. In bounding analyses, we assigned children with missing grade information hypothetical achievement levels - either low or high achieving. Reassuringly, our main finding that the school closures increased the learning-time gap by student achievement turns out robust in this attrition analysis (detailed results available upon request).

15 The small number of observable differences likely reflects that the analysis neglects any variation between school types and that it is based on a multivariate model that holds the other variables constant. In fact, regressing the high-achievement dummy on each characteristic separately (accounting only for school-type dummies) yields the following significant coefficients $(p<0.05)$ in addition to the ones in column 2 of Appendix Tables A3: parental university degree (positive), child not in household (negative), parental work hours (positive), and household income (positive). Detailed results are available upon request.

${ }^{16}$ Question wording: "The following questions are about your youngest child attending school. What activities did your child do on a typical workday (Monday to Friday) before [during] the several weeks of Corona-related school closures?" The sum of reported hours spent per day was prevented from exceeding 24 hours. In our analysis, outliers in any answer category are top-coded at $12 \mathrm{~h}$.

${ }^{17}$ In cases where the activity specified in the open field corresponded to existing categories, we re-coded the respective category accordingly.
} 
Table 1

Activities of low- and high-achieving students before and during the school closures.

\begin{tabular}{|c|c|c|c|c|c|c|c|c|c|c|c|c|}
\hline & \multicolumn{4}{|l|}{ During Corona } & \multicolumn{4}{|l|}{ Before Corona } & \multicolumn{4}{|c|}{ Difference during-before } \\
\hline & $\begin{array}{l}\text { Low-achievers } \\
\text { (1) }\end{array}$ & $\begin{array}{l}\text { High-achievers } \\
\text { (2) }\end{array}$ & $\begin{array}{l}\text { Gap } \\
\text { (3) }\end{array}$ & $\begin{array}{l}\text { Std. err. } \\
\text { (4) }\end{array}$ & $\begin{array}{l}\text { Low-achievers } \\
\text { (5) }\end{array}$ & $\begin{array}{l}\text { High-achievers } \\
\text { (6) }\end{array}$ & $\begin{array}{l}\text { Gap } \\
\text { (7) }\end{array}$ & $\begin{array}{l}\text { Std. err. } \\
\text { (8) }\end{array}$ & $\begin{array}{l}\text { Low-achievers } \\
\text { (9) }\end{array}$ & $\begin{array}{l}\text { High-achievers } \\
\text { (10) }\end{array}$ & $\begin{array}{l}\text { Gap } \\
\text { (11) }\end{array}$ & $\begin{array}{l}\text { Std. err. } \\
\text { (12) }\end{array}$ \\
\hline \multicolumn{13}{|l|}{ School activities } \\
\hline Aggregate & 3.36 & 3.85 & 0.496 & $(0.151)^{* * *}$ & 7.42 & 7.50 & 0.079 & $(0.130)$ & -4.07 & -3.65 & 0.416 & $(0.180)^{* *}$ \\
\hline Attending school & 0.82 & 0.92 & 0.103 & $(0.133)$ & 5.93 & 5.93 & -0.003 & $(0.116)$ & -5.11 & -5.01 & 0.105 & $(0.177)$ \\
\hline Learning for school & 2.54 & 2.93 & 0.393 & $(0.102)^{* * * *}$ & 1.49 & 1.58 & 0.082 & $(0.067)$ & 1.04 & 1.35 & 0.311 & $(0.108)^{* * * *}$ \\
\hline \multicolumn{13}{|l|}{ Conducive activities } \\
\hline Aggregate & 2.79 & 3.37 & 0.580 & $(0.128)^{* * * *}$ & 2.61 & 3.01 & 0.403 & $(0.107)^{* * *}$ & 0.19 & 0.36 & 0.177 & $(0.107)^{*}$ \\
\hline Reading & 0.63 & 0.86 & 0.237 & $(0.046)^{* * *}$ & 0.54 & 0.74 & 0.201 & $(0.039) * * *$ & 0.09 & 0.12 & 0.036 & $(0.041)$ \\
\hline Music and creative work & 0.66 & 0.82 & 0.164 & $(0.061)^{* * *}$ & 0.53 & 0.65 & 0.117 & $(0.046)^{* *}$ & 0.13 & 0.17 & 0.047 & $(0.047)$ \\
\hline Physical exercise & 1.51 & 1.69 & 0.179 & $(0.080)^{* *}$ & 1.53 & 1.62 & 0.085 & $(0.067)$ & -0.03 & 0.07 & 0.094 & $(0.077)$ \\
\hline \multicolumn{13}{|l|}{ Detrimental activities } \\
\hline Aggregate & 6.29 & 4.84 & -1.452 & $(0.210)^{* * *}$ & 4.58 & 3.82 & -0.762 & $(0.156)^{* * *}$ & 1.71 & 1.02 & -0.691 & $(0.146)^{* * *}$ \\
\hline Watching TV & 1.50 & 1.37 & -0.126 & $(0.070)^{*}$ & 1.24 & 1.18 & -0.059 & $(0.058)$ & 0.26 & 0.20 & -0.067 & $(0.051)$ \\
\hline Gaming & 1.87 & 1.32 & -0.550 & $(0.101)^{* * * *}$ & 1.23 & 0.99 & -0.244 & $(0.068) * * *$ & 0.64 & 0.34 & -0.306 & $(0.068)^{* * * *}$ \\
\hline Social media & 1.77 & 1.18 & -0.593 & $(0.097)^{* * * *}$ & 1.22 & 0.90 & -0.321 & $(0.067)^{* * *}$ & 0.55 & 0.28 & -0.272 & $(0.067)^{* * * *}$ \\
\hline Online media & 1.15 & 0.97 & -0.184 & $(0.067)^{* * *}$ & 0.89 & 0.76 & -0.137 & $(0.047)^{* * * *}$ & 0.26 & 0.21 & -0.046 & $(0.056)$ \\
\hline
\end{tabular}

Notes: Average hours spent on different activities on a typical workday. During Corona: period of school closures due to COVID-19. Before Corona: period before the school closures. Low- versus high-

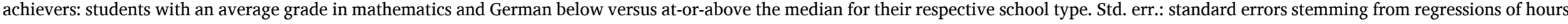
spent on each activity on a high-achiever indicator. Significance levels: ${ }^{* * *} p<0.01,{ }^{* *} \mathrm{p}<0.5,{ }^{*} \mathrm{p}<0.1$. Data source: ifo Education Survey 2020. 


\section{School activities}

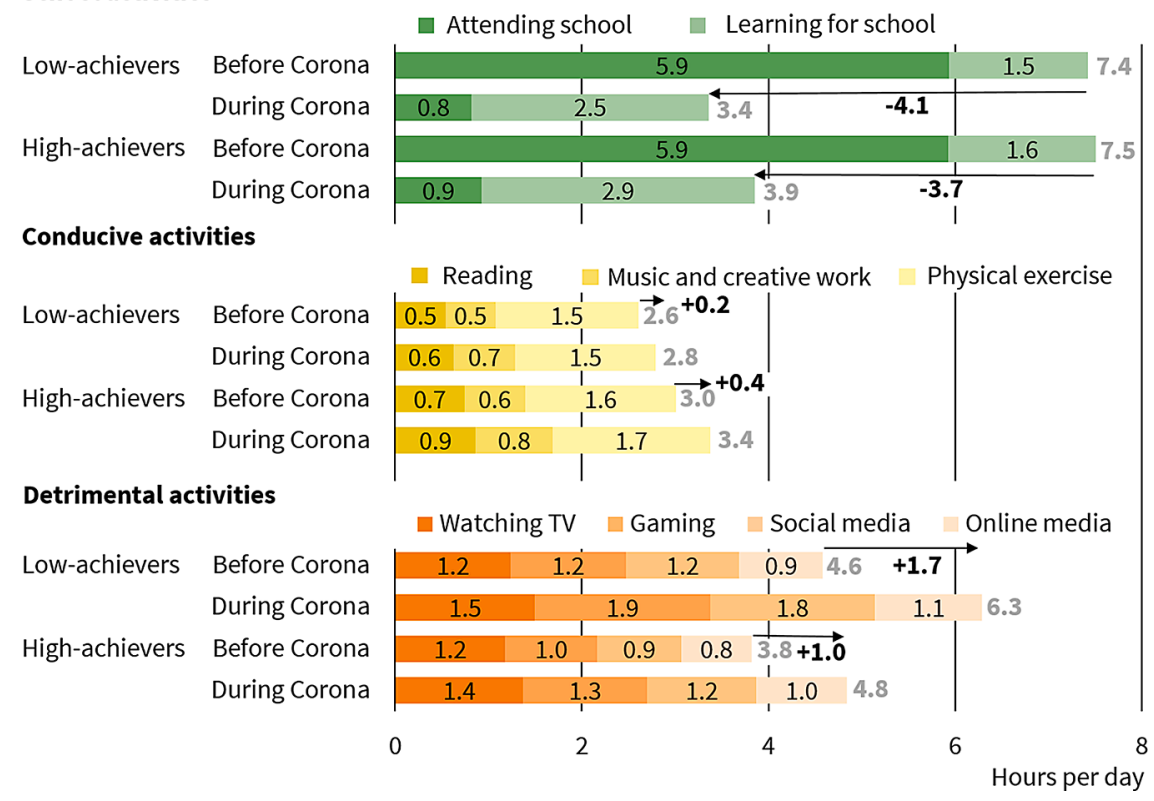

Fig. 1. Activities of low- and high-achieving students before and during the school closures

Notes: Average hours spent on different activities on a typical workday. During Corona: period of school closures due to COVID-19. Before Corona: period before the school closures. Low- versus high-achievers: students with an average grade in mathematics and German below versus at-or-above the median for their respective school type. See Table 1 for details. Data source: ifo Education Survey 2020.

\section{Time use of low- and high-achieving students before and during the school closures}

This section reports results on how the COVID-19 school closures differentially affected low- and high-achieving students' learning time (Section 4.1), as well as their time investment in other conducive and detrimental activities (Section 4.2).

\subsection{Learning time}

To be able to investigate how the gap in learning time between low- and high-achieving students changed over time, we elicited information on time use for school-related activities on a typical workday both before and during the school closures. The schoolrelated activities include the two sub-categories of attending school and learning for school at home.

In the full sample, the school closures more than halved students' learning time. Before the school closures, students spent on average $7.4 \mathrm{~h}$ per day on school-related activities (Appendix Tables A5). This number dropped to $3.6 \mathrm{~h}$ during the closures. This reduction is due to a large decline in school attendance - from an average of 5.9 to $0.9 \mathrm{~h}$ (emergency services) per day - that is hardly compensated by a much smaller increase in time spent on learning for school (from 1.5 to $2.7 \mathrm{~h}$ ).

Differentiating between low- and high-achieving students reveals that the school closures strongly increased educational inequality. Columns 5-8 of Table 1 indicate that learning time before the school closures did not differ economically or statistically significantly between students initially achieving below versus at-or-above the median (7.4 versus $7.5 \mathrm{~h}$ per day). ${ }^{18}$ By contrast, columns 1-4 show that high-achieving students spent $0.5 \mathrm{~h}$ more on school-related activities during the closures (3.4 versus $3.9 \mathrm{~h}$, $p<0.01) .{ }^{19}$ Consequently, the increase in the learning-time gap between low- and high-achieving students relative to pre-closure times (columns 9-12) is a significant $0.4 \mathrm{~h}$ per day ( -4.1 versus $-3.7 \mathrm{~h}$ for low- and high-achievers, respectively; see also Fig. 1). Beyond the binary achievement indicator of our baseline analysis, Appendix Fig. A1 shows that the relationship between the reduction in learning time and student achievement is visible across the entire grade spectrum. E.g., learning time decreases by $3.6 \mathrm{~h}$ in the top and $4.2 \mathrm{~h}$ in the bottom of the five grade categories. Distinguishing between the two sub-categories of school-related activities, the decrease in school attendance was similar for low- and high-achievers ( -5.1 versus $-5.0 \mathrm{~h}$ ), but low-achievers increased home learning less than high-achievers $(+1.0$ versus $+1.4 \mathrm{~h})$.

\footnotetext{
18 Throughout, average results for the full sample are not a simple weighted average of high- and low achieving students because they include students who do not yet receive grades.

19 The difference in learning time between low- and high-achieving students during the school closures is visible throughout the entire distribution (Appendix Tables A6). For example, 43\% of low-achievers spent at most two hours per day on school-related activities, compared to 33\% of highachievers. Only 22 versus $30 \%$, respectively, spent more than four hours per day on learning. For comparison, before the school closures 89 percent of students spent at least five hours per day on learning.
} 


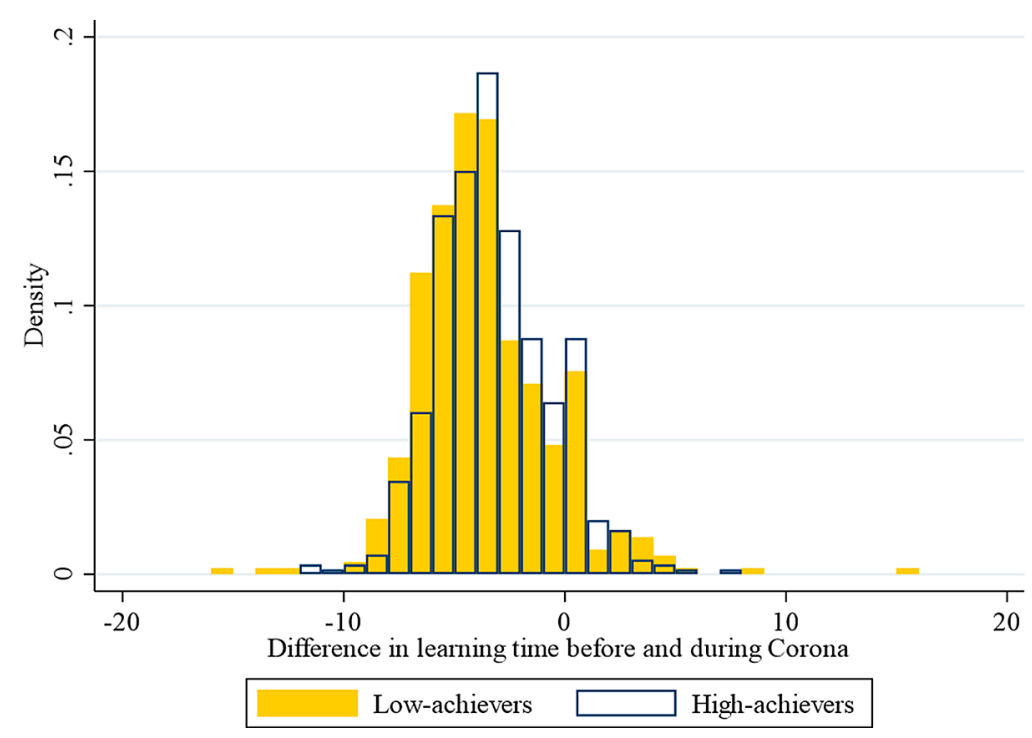

Fig. 2. Distribution of reduction in learning time by student achievement

Notes: Difference in average hours spent on school activities on a typical workday between the period before the school closures and the period of school closures due to COVID-19. Low- versus high-achievers: students with an average grade in mathematics and German below versus at-or-above the median for their respective school type. A two-sample Kolmogorov-Smirnov test rejects equality of the two depicted distributions with a $p$-value of 0.014. Data source: ifo Education Survey 2020.

Going beyond mean differences between low- and high-achieving students, Fig. 2 depicts the respective distributions of learningtime losses for the two groups. The distribution of low-achievers is consistently shifted to the left (towards greater learning-time losses) compared to high-achievers. A two-sample Kolmogorov-Smirnov test rejects the null hypothesis that learning-time losses do not differ by student achievement $(p=0.014)$. Thus, average differences in learning-time losses as reported in Table 1 are not driven by extreme outliers but are rather observable throughout the distribution.

The learning-time gap between low- and high-achieving students can hardly be accounted for by other observed student and parent characteristics. Table 2 shows results of regressions of the learning time during the school closures on a high-achiever dummy, learning time before the school closures, and a series of student and parent characteristics: the student's school type, age, gender, a single-child dummy, the responding parent's gender, education, single-parent status, home-office status and work hours during the school closures, partner at home during the school closures, household income, and a West-Germany dummy. In all cases, including the additional variables leaves the difference between high- and low-achieving students highly significant and of similar magnitude as the unconditional gap. ${ }^{20}$ Including all controls simultaneously (column 14) reduces the difference in learning time between high- and lowachieving students by less than one quarter. Thus, most of the large gap does not reflect differences in the observed characteristics, but rather seems to capture the genuine achievement dimension.

\subsection{Other conducive and detrimental activities}

Substituting the reduced learning time, both low- and high-achieving students only mildly increased the time spent on other activities that are generally viewed as conducive for child development. During the school closures, high-achievers (3.4 h) spent significantly more time on reading, playing music, creative work, or physical exercise than low-achievers ( $2.8 \mathrm{~h}$; see middle panel of Table 1). However, most of this gap existed already before the closures, so that the difference in the increase in these conducive activities is only marginally significant $(+0.2$ versus $+0.4 \mathrm{~h}$ for low- and high-achievers, respectively, $p<0.1)$.

By contrast, low-achieving students particularly used the released time to expand activities such as gaming on the computer or consuming social media. During the school closures, low-achieving students spent $6.3 \mathrm{~h}$ on activities such as watching TV, playing computer games, and consuming social and online media that are generally deemed detrimental to child development (bottom panel of Table 1) - nearly three hours more each day than on school-related activities. In comparison, high-achievers spent $1.5 \mathrm{~h}$ less on the detrimental activities. Roughly half of this gap already existed before the school closures, so that the increase in time spent on detrimental activities was $0.7 \mathrm{~h}$ larger for low- compared to high-achieving students $(+1.7$ versus $+1.0 \mathrm{~h})$. The increase is mostly driven by increased gaps in computer gaming and social-media use, each of which increased by $0.3 \mathrm{~h}$.

\footnotetext{
${ }^{20}$ In fact, the only noteworthy reduction does not come from any of the measures of socioeconomic background or family situation, but rather from student age (column 3), reflecting that younger students tend to get better grades and had a smaller reduction in learning time (due to lower beforeCorona levels).
} 
Table 2

Gap in learning time between low- and high-achieving students conditional on student and parent characteristics.

\begin{tabular}{|c|c|c|c|c|c|c|c|c|c|c|c|c|c|c|}
\hline & (1) & (2) & (3) & (4) & (5) & (6) & (7) & (8) & (9) & (10) & (11) & (12) & (13) & (14) \\
\hline High-achiever & $\begin{array}{l}0.478^{* * * *} \\
(0.149)\end{array}$ & $\begin{array}{l}0.474 * * * \\
(0.149)\end{array}$ & $\begin{array}{l}0.417^{* * * *} \\
(0.151)\end{array}$ & $\begin{array}{l}0.455^{* * *} \\
(0.148)\end{array}$ & $\begin{array}{l}0.478^{* * * *} \\
(0.149)\end{array}$ & $\begin{array}{l}0.460^{* * * *} \\
(0.149)\end{array}$ & $\begin{array}{l}0.463^{* * * *} \\
(0.149)\end{array}$ & $\begin{array}{l}0.483^{* * * *} \\
(0.149)\end{array}$ & $\begin{array}{l}0.460^{* * * *} \\
(0.150)\end{array}$ & $\begin{array}{l}0.478^{* * * *} \\
(0.149)\end{array}$ & $\begin{array}{l}0.475^{* * *} \\
(0.149)\end{array}$ & $\begin{array}{l}0.492^{* * * *} \\
(0.149)\end{array}$ & $\begin{array}{l}0.461^{* * * *} \\
(0.149)\end{array}$ & $\begin{array}{l}0.368^{* * *} \\
(0.151)\end{array}$ \\
\hline School activities before Corona & $\begin{array}{l}0.224^{* * *} \\
(0.036)\end{array}$ & $\begin{array}{l}0.218^{* * * *} \\
(0.037)\end{array}$ & $\begin{array}{l}0.244^{* * *} \\
(0.037)\end{array}$ & $\begin{array}{l}0.219^{* * *} \\
(0.036)\end{array}$ & $\begin{array}{l}0.224^{* * *} \\
(0.036)\end{array}$ & $\begin{array}{l}0.229^{* * * *} \\
(0.036)\end{array}$ & $\begin{array}{l}0.222^{* * *} \\
(0.036)\end{array}$ & $\begin{array}{l}0.225^{* * *} \\
(0.038)\end{array}$ & $\begin{array}{l}0.227^{* * * *} \\
(0.036)\end{array}$ & $\begin{array}{l}0.224^{* * *} \\
(0.037)\end{array}$ & $\begin{array}{l}0.224^{* * *} \\
(0.036)\end{array}$ & $\begin{array}{l}0.232^{* * * *} \\
(0.037)\end{array}$ & $\begin{array}{l}0.219^{* * * *} \\
(0.036)\end{array}$ & $\begin{array}{l}0.240^{* * * *} \\
(0.038)\end{array}$ \\
\hline $\begin{array}{l}\text { Upper-track secondary } \\
\text { school (Gymnasium) }\end{array}$ & & $\begin{array}{l}0.120 \\
(0.191)\end{array}$ & & & & & & & & & & & & $\begin{array}{l}0.146 \\
(0.232)\end{array}$ \\
\hline Other secondary school & & $\begin{array}{l}-0.286 \\
(0.183)\end{array}$ & & & & & & & & & & & & $\begin{array}{l}0.687^{* * *} \\
(0.254)\end{array}$ \\
\hline Age & & & $\begin{array}{l}-0.053^{* * *} \\
(0.023)\end{array}$ & & & & & & & & & & & $\begin{array}{l}-0.095^{* * *} \\
(0.032)\end{array}$ \\
\hline Girl & & & & $\begin{array}{l}0.477^{* * *} \\
(0.147)\end{array}$ & & & & & & & & & & $\begin{array}{l}0.486^{* * *} \\
(0.147)\end{array}$ \\
\hline Single child & & & & & $\begin{array}{l}-0.062 \\
(0.152)\end{array}$ & & & & & & & & & $\begin{array}{l}-0.142 \\
(0.153)\end{array}$ \\
\hline Parent female & & & & & & $\begin{array}{l}-0.286^{*} \\
(0.148)\end{array}$ & & & & & & & & $\begin{array}{l}-0.299^{*} \\
(0.161)\end{array}$ \\
\hline Parent has university degree & & & & & & & $\begin{array}{l}0.185 \\
(0.167)\end{array}$ & & & & & & & $\begin{array}{l}0.113 \\
(0.188)\end{array}$ \\
\hline Single parent & & & & & & & & $\begin{array}{l}-0.079 \\
(0.205)\end{array}$ & & & & & & $\begin{array}{l}-0.006 \\
(0.222)\end{array}$ \\
\hline Child not in household & & & & & & & & $\begin{array}{l}0.146 \\
(0.271)\end{array}$ & & & & & & $\begin{array}{l}0.043 \\
(0.281)\end{array}$ \\
\hline Parent in home office & & & & & & & & & $\begin{array}{l}0.183 \\
(0.157)\end{array}$ & & & & & $\begin{array}{l}0.170 \\
(0.174)\end{array}$ \\
\hline Parent work hours & & & & & & & & & & $\begin{array}{l}0.000 \\
(0.004)\end{array}$ & & & & $\begin{array}{l}-0.001 \\
(0.005)\end{array}$ \\
\hline Partner at home & & & & & & & & & & & $\begin{array}{l}0.172 \\
(0.189)\end{array}$ & & & $\begin{array}{l}0.172 \\
(0.196)\end{array}$ \\
\hline Household income & & & & & & & & & & & & $\begin{array}{l}-0.001^{*} \\
(0.000)\end{array}$ & & $\begin{array}{l}-0.012^{* *} \\
(0.005)\end{array}$ \\
\hline West Germany & & & & & & & & & & & & & $\begin{array}{l}-0.399^{* * *} \\
(0.184)\end{array}$ & $\begin{array}{l}-0.390^{* * *} \\
(0.185)\end{array}$ \\
\hline Constant & 1.692 & 1.805 & 2.260 & 1.504 & 1.719 & 1.809 & 1.665 & 1.683 & 1.616 & 1.692 & 1.662 & 1.881 & 2.058 & 3.132 \\
\hline Observations & 983 & 983 & 983 & 982 & 983 & 983 & 983 & 983 & 982 & 983 & 983 & 980 & 983 & 978 \\
\hline$R^{2}$ & 0.0476 & 0.0530 & 0.0527 & 0.0570 & 0.0477 & 0.0512 & 0.0488 & 0.0481 & 0.0501 & 0.0476 & 0.0484 & 0.0504 & 0.0521 & 0.0895 \\
\hline
\end{tabular}

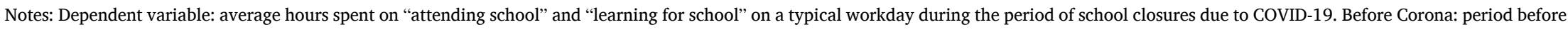
the school closures. Low- versus high-achievers: students with an average grade in mathematics and German below versus at-or-above the median for their respective school type. Significance levels: *** $p<0.01,{ }^{* *} \mathrm{p}<0.5,{ }^{*} \mathrm{p}<0.1$. Data source: ifo Education Survey 2020. 
Together, the results indicate that the school closures exacerbated educational inequality along the achievement dimension. The findings suggest that COVID-19 (i) increased the gap in learning time (and, mildly, in other conducive activities) between high- and low achieving students and (ii) increased detrimental activities especially among low-achieving students. Since low-achieving students are, basically by definition, less effective in turning learning-time inputs into knowledge and skills, we interpret the pronounced effect of the school closures on students' learning-time gaps as lower bound for the impact on gaps in actual learning. ${ }^{21}$

\section{Compensating activities by parents and schools}

This section investigates to what extent parents (Section 5.1) and schools (Section 5.2) acted to compensate for the increased gap in learning time between low- and high-achieving students.

\subsection{Parental support}

While parents of both low- and high-achieving students increased the time they spent together with their child on learning during the school closures, both level and increase were smaller for low-achievers. ${ }^{22}$ During the school closures, low-achievers spent $0.3 \mathrm{~h}$ per day less learning together with their parents than high-achievers ( 0.9 versus $1.2 \mathrm{~h}, p<0.01$; Table 3 ). While part of this gap already existed before the closures, it further increased by $0.1 \mathrm{~h}$ during the school closures $(p<0.1)$. Thus, even though parents increased the learning involvement with their children by half an hour per day during the closures, this aggravated rather than compensated for the increase in educational inequality.

By contrast, the increase in time spent together with parents on other conducive and on detrimental activities did not differ statistically significantly between low- and high-achievers. Still, parents of high-achieving students also spent significantly more time with their child on other conducive activities both before and during the school closures ${ }^{23}$.

Parents' assessment of the environment at home reinforces the finding that low-achieving students were more affected by the COVID-19 school closures. While most parents (87\%) think that their family has coped well with the period of school closures (Appendix Tables A7), parents of low-achieving students evaluate the situation slightly worse than parents of high-achieving students (85 versus $90 \%, p<0.05)$. There is no significant difference between low- and high-achieving students in whether parents report that the phase of the school closures was a psychological burden for the child or for themselves (38\% each on average). By contrast, parents of low-achievers are slightly more likely than parents of high-achievers to report that during the school closures, they argued more than usual with their child ( 30 versus $24 \%, p<0.1$ ). They also assess the overall learning environment at home (e.g., in terms of available computers or working space) worse. These gaps hardly change when conditioning on observable child and parent characteristics (column 6).

\subsection{School support}

During the closures, schools and teachers carried out only a fraction of their usual teaching operations via distance teaching, which led to a drastic reduction in direct communication between teachers and students. Table 4 indicates that only $29 \%$ of students on average had online lessons for the whole class (e.g., by video call) more than once a week. Only $17 \%$ of students had individual contact with their teacher more than once a week. ${ }^{24}$ The main teaching mode during the school closures was to provide students with exercise sheets for independent processing (87\%), ${ }^{25}$ although only $37 \%$ received feedback on the completed exercises more than once a week. School activities strongly correlate with children's learning time during the school closures: Children in schools with above-median intensity of distance teaching (with respect to online lessons, individual teacher-student contacts, and feedback on exercises) spent a significant $0.4 \mathrm{~h}$ more time on learning for school a day ( $2.92 \mathrm{~h}$ versus $2.55 \mathrm{~h}$ ).

The distance-teaching measures over-proportionally reached high-achieving students. Low-achievers were 13 percentage points less likely than high-achievers to be taught in online lessons and 10 percentage points less likely to have individual contact with their teachers (column 4). Low-achievers were also less likely to be provided with educational videos or software and to receive feedback on their completed tasks. These gaps do not change noticeably when conditioning on child and parental characteristics (column 6). Thus,

\footnotetext{
${ }^{21}$ Consistently, parents of low-achievers are 14 percentage points more likely than parents of high-achievers to report that their child learned "much less" during the school closures than usual (Appendix Tables A7).

${ }^{22}$ The importance of parental inputs for children's skill development is underscored by the finding that children's educational activities are particularly productive when parents are involved (Fiorini and Keane, 2014).

${ }^{23}$ In additional analyses, we find that parent involvement in learning and other conducive activities before and during the school closures decreases with child age, as does the increase in parental involvement in these activities induced by the school closures (detailed results available upon request).

${ }^{24}$ Across the five answer categories, 6 (4)\% had joint online lessons (individual teacher contact) on a daily basis, 23 (14)\% several times a week, 14 (16)\% once a week, $11(22) \%$ less than once a week, and $45(45) \%$ never.

$2596 \%$ of students received exercises at least once a week.
} 
Table 3

Parental involvement in activities of low- and high-achieving students.

\begin{tabular}{|c|c|c|c|c|c|c|c|c|c|c|c|c|}
\hline & \multicolumn{4}{|l|}{ During Corona } & \multicolumn{4}{|l|}{ Before Corona } & \multicolumn{4}{|c|}{ Difference during-before } \\
\hline & $\begin{array}{l}\text { Low-achievers } \\
\text { (1) }\end{array}$ & $\begin{array}{l}\text { High-achievers } \\
\text { (2) }\end{array}$ & $\begin{array}{l}\text { Gap } \\
\text { (3) }\end{array}$ & $\begin{array}{l}\text { Std. err. } \\
\text { (4) }\end{array}$ & $\begin{array}{l}\text { Low-achievers } \\
\text { (5) }\end{array}$ & $\begin{array}{l}\text { High-achievers } \\
\text { (6) }\end{array}$ & $\begin{array}{l}\text { Gap } \\
\text { (7) }\end{array}$ & $\begin{array}{l}\text { Std. err. } \\
\text { (8) }\end{array}$ & $\begin{array}{l}\text { Low-achievers } \\
\text { (9) }\end{array}$ & $\begin{array}{l}\text { High-achievers } \\
\text { (10) }\end{array}$ & $\begin{array}{l}\text { Gap } \\
\text { (11) }\end{array}$ & $\begin{array}{l}\text { Std. err. } \\
\text { (12) }\end{array}$ \\
\hline \multicolumn{13}{|l|}{ School activities } \\
\hline Aggregate & 0.89 & 1.20 & 0.311 & $(0.079) * * *$ & 0.42 & 0.62 & 0.193 & $(0.044)^{* * * *}$ & 0.47 & 0.59 & 0.118 & $(0.069)^{*}$ \\
\hline \multicolumn{13}{|l|}{ Conducive activities } \\
\hline Aggregate & 1.07 & 1.47 & 0.398 & $(0.099)^{* * * *}$ & 0.78 & 1.11 & 0.325 & $(0.087)^{* * *}$ & 0.29 & 0.36 & 0.073 & $(0.077)$ \\
\hline Reading & 0.22 & 0.34 & 0.121 & $(0.033)^{* * * *}$ & 0.18 & 0.30 & 0.124 & $(0.030)^{* * *}$ & 0.04 & 0.04 & -0.002 & $(0.026)$ \\
\hline Music and creative work & 0.20 & 0.28 & 0.086 & $(0.033)^{* * *}$ & 0.17 & 0.23 & 0.060 & $(0.028)^{* *}$ & 0.03 & 0.06 & 0.026 & $(0.030)$ \\
\hline Physical exercise & 0.66 & 0.85 & 0.191 & $(0.063)^{* * * *}$ & 0.44 & 0.58 & 0.142 & $(0.050)^{* * *}$ & 0.22 & 0.27 & 0.050 & $(0.057)$ \\
\hline \multicolumn{13}{|l|}{ Detrimental activities } \\
\hline Aggregate & 1.36 & 1.45 & 0.094 & $(0.132)$ & 1.03 & 1.23 & 0.200 & $(0.109)^{*}$ & 0.32 & 0.22 & -0.106 & $(0.090)$ \\
\hline Watching TV & 0.68 & 0.73 & 0.047 & $(0.058)$ & 0.52 & 0.62 & 0.101 & $(0.049)^{* * *}$ & 0.16 & 0.11 & -0.053 & $(0.047)$ \\
\hline Gaming & 0.23 & 0.24 & 0.003 & $(0.044)$ & 0.18 & 0.22 & 0.037 & $(0.035)$ & 0.05 & 0.02 & -0.035 & $(0.033)$ \\
\hline Social media & 0.24 & 0.24 & -0.005 & $(0.053)$ & 0.18 & 0.20 & 0.016 & $(0.040)$ & 0.06 & 0.04 & -0.021 & $(0.039)$ \\
\hline Online media & 0.19 & 0.24 & 0.049 & $(0.034)$ & 0.15 & 0.19 & 0.046 & $(0.028)$ & 0.05 & 0.05 & 0.003 & $(0.030)$ \\
\hline
\end{tabular}

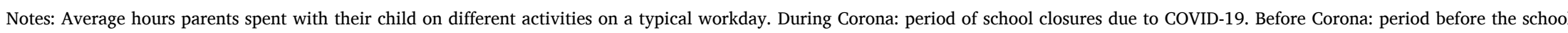

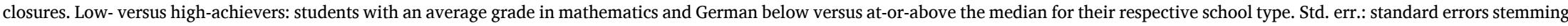
from regressions of hours spent on each activity on a high-achiever indicator. Significance levels: ${ }^{* * *} p<0.01,{ }^{* *} \mathrm{p}<0.5$, * $\mathrm{p}<0.1$. Data source: ifo Education Survey 2020 . 
Table 4

Schools' distance-teaching activities during the school closures for low- and high-achieving students.

\begin{tabular}{|c|c|c|c|c|c|c|c|}
\hline & \multirow[b]{2}{*}{$\begin{array}{l}\text { Average } \\
\text { (1) }\end{array}$} & \multirow[b]{2}{*}{$\begin{array}{l}\text { Low-achievers } \\
\text { (2) }\end{array}$} & \multirow[b]{2}{*}{$\begin{array}{l}\text { High-achievers } \\
\text { (3) }\end{array}$} & \multicolumn{2}{|c|}{ Unconditional gap } & \multicolumn{2}{|c|}{ Conditional gap } \\
\hline & & & & $\begin{array}{l}\text { Gap } \\
(4)\end{array}$ & $\begin{array}{l}\text { Std. err. } \\
\text { (5) }\end{array}$ & $\begin{array}{l}\text { Gap } \\
(6)\end{array}$ & $\begin{array}{l}\text { Std. err. } \\
\text { (7) }\end{array}$ \\
\hline Shared lessons (e.g., by video call) & 0.29 & 0.24 & 0.37 & 0.131 & $(0.029)^{* * *}$ & 0.131 & $(0.031)^{* * *}$ \\
\hline Individual contact with teacher & 0.17 & 0.13 & 0.23 & 0.102 & $(0.025)^{* * *}$ & 0.081 & $(0.026)^{* * *}$ \\
\hline Educational videos or texts & 0.53 & 0.47 & 0.59 & 0.118 & $(0.032)^{* * *}$ & 0.115 & $(0.034)^{* * *}$ \\
\hline Educational software & 0.43 & 0.40 & 0.47 & 0.078 & $(0.032)^{* *}$ & 0.068 & $(0.034)^{* *}$ \\
\hline Child received exercises & 0.87 & 0.84 & 0.89 & 0.049 & $(0.022)^{* *}$ & 0.042 & $(0.023)^{*}$ \\
\hline Child had to submit exercises & 0.51 & 0.51 & 0.55 & 0.033 & $(0.032)$ & 0.054 & $(0.033)$ \\
\hline Child received feedback on exercises & 0.37 & 0.34 & 0.42 & 0.078 & $(0.031)^{* *}$ & 0.096 & $(0.033)^{* * *}$ \\
\hline
\end{tabular}

Notes: Probability that the respective activity was conducted "daily" or "several times a week" (residual category includes "once a week," "less than once a week," and "never"). Question wording: "Which activities did the teachers/school of your child carry out during the several weeks of Coronarelated school closures? Shared lessons for the whole class (e.g., by video call or telephone); Individual contact with my child (e.g., by video call or telephone); My child should watch provided educational videos or read texts; My child should use educational software or programs; My child should work on provided exercises; My child had to submit completed exercises; Teachers gave feedback on the completed exercises." Low- versus highachievers: students with an average grade in mathematics and German below versus at-or-above the median for their respective school type. Std. err.: standard errors stemming from regressions of an indicator that the respective activity was conducted at least several times a week on a highachiever indicator. Conditional gap: see Table 2 for controls. Significance levels: *** $p<0.01,{ }^{* *} \mathrm{p}<0.5$, * $\mathrm{p}<0.1$. Data source: ifo Education Survey 2020 .

Table 5

Student activities before and during the school closures by parental education and by students' gender.

\begin{tabular}{|c|c|c|c|c|c|c|c|c|c|c|c|c|}
\hline & \multicolumn{4}{|c|}{ During Corona } & \multicolumn{4}{|c|}{ Before Corona } & \multicolumn{4}{|c|}{ Difference during-before } \\
\hline & (1) & (2) & (3) & (4) & (5) & $(6)$ & (7) & (8) & (9) & $(10)$ & (11) & (12) \\
\hline & Low-ed & High-ed & Gap & Std. err. & Low-ed & High-ed & Gap & Std. err. & Low-ed & High-ed & Gap & Std. err. \\
\hline \multicolumn{13}{|l|}{ School activities } \\
\hline Aggregate & 3.55 & 3.82 & 0.275 & $(0.162)^{*}$ & 7.37 & 7.55 & 0.178 & $(0.136)$ & -3.83 & -3.73 & 0.097 & $(0.189)$ \\
\hline Attending school & 0.85 & 1.04 & 0.190 & $(0.143)$ & 5.91 & 5.92 & 0.013 & $(0.122)$ & -5.06 & -4.88 & 0.177 & $(0.185)$ \\
\hline Learning for school & 2.70 & 2.78 & 0.085 & $(0.107)$ & 1.46 & 1.63 & 0.165 & $(0.070)^{* *}$ & 1.23 & 1.15 & -0.080 & $(0.114)$ \\
\hline \multicolumn{13}{|l|}{ Conducive activities } \\
\hline Aggregate & 3.10 & 3.48 & 0.380 & $(0.138) * * *$ & 2.86 & 2.98 & 0.122 & $(0.114)$ & 0.24 & 0.50 & 0.258 & $(0.113)^{* *}$ \\
\hline Reading & 0.73 & 0.87 & 0.141 & $(0.048)^{* * * *}$ & 0.63 & 0.76 & 0.128 & $(0.042)^{* * *}$ & 0.10 & 0.11 & 0.013 & $(0.043)$ \\
\hline Music and creative work & 0.70 & 0.95 & 0.249 & $(0.064)^{* * * *}$ & 0.57 & 0.73 & 0.161 & $(0.048) * * *$ & 0.13 & 0.22 & 0.088 & $(0.051)^{*}$ \\
\hline Physical exercise & 1.67 & 1.66 & -0.010 & $(0.088)$ & 1.66 & 1.50 & -0.166 & $(0.072)^{* *}$ & 0.01 & 0.16 & 0.156 & $(0.083) *$ \\
\hline \multicolumn{13}{|l|}{ Detrimental activities } \\
\hline Aggregate & 5.48 & 4.54 & -0.934 & $(0.223)^{* * *}$ & 4.17 & 3.41 & -0.759 & $(0.164)^{* * * *}$ & 1.31 & 1.13 & -0.175 & $(0.150)$ \\
\hline Watching TV & 1.48 & 1.25 & -0.237 & $(0.072) * * *$ & 1.26 & 1.04 & -0.221 & $(0.060) * * *$ & 0.23 & 0.21 & -0.016 & $(0.053)$ \\
\hline Gaming & 1.55 & 1.33 & -0.225 & $(0.106) * *$ & 1.10 & 0.91 & -0.189 & $(0.070)^{* * *}$ & 0.46 & 0.42 & -0.036 & $(0.070)$ \\
\hline Social media & 1.42 & 1.01 & -0.409 & $(0.102)^{* * * *}$ & 1.04 & 0.72 & -0.318 & $(0.070)^{* * *}$ & 0.38 & 0.29 & -0.092 & $(0.068)$ \\
\hline \multirow[t]{2}{*}{ Online media } & 1.02 & 0.96 & -0.062 & $(0.070)$ & 0.78 & 0.75 & -0.031 & $(0.050)$ & 0.24 & 0.21 & -0.031 & $(0.057)$ \\
\hline & Boy & Girl & Gap & Std. err. & Boy & Girl & Gap & Std. err. & Boy & Girl & Gap & Std. err. \\
\hline \multicolumn{13}{|l|}{ School activities } \\
\hline Aggregate & 3.36 & 3.89 & 0.525 & $(0.143) * * *$ & 7.40 & 7.44 & 0.039 & $(0.121)$ & -4.04 & -3.55 & 0.486 & $(0.168)^{* * * *}$ \\
\hline Attending school & 0.88 & 0.91 & 0.026 & $(0.127)$ & 5.91 & 5.92 & 0.016 & $(0.109)$ & -5.02 & -5.01 & 0.010 & $(0.164)$ \\
\hline Learning for school & 2.48 & 2.98 & 0.499 & $(0.094) * * *$ & 1.50 & 1.52 & 0.022 & $(0.063)$ & 0.98 & 1.46 & 0.476 & $(0.100)^{* * *}$ \\
\hline \multicolumn{13}{|l|}{ Conducive activities } \\
\hline Aggregate & 3.08 & 3.34 & 0.260 & $(0.123)^{* *}$ & 2.85 & 2.94 & 0.087 & $(0.102)$ & 0.23 & 0.40 & 0.173 & $(0.101)^{*}$ \\
\hline Reading & 0.72 & 0.82 & 0.102 & $(0.043)^{* *}$ & 0.65 & 0.68 & 0.032 & $(0.038)$ & 0.07 & 0.14 & 0.071 & $(0.038)^{*}$ \\
\hline Music and creative work & 0.65 & 0.90 & 0.253 & $(0.057)^{* * *}$ & 0.55 & 0.68 & 0.128 & $(0.043)^{* * *}$ & 0.10 & 0.22 & 0.125 & $(0.046)^{* * *}$ \\
\hline Physical exercise & 1.71 & 1.62 & -0.096 & $(0.079)$ & 1.65 & 1.58 & -0.073 & $(0.064)$ & 0.06 & 0.04 & -0.023 & $(0.075)$ \\
\hline \multicolumn{13}{|l|}{ Detrimental activities } \\
\hline Aggregate & 5.57 & 4.85 & -0.716 & $(0.199) * * *$ & 4.19 & 3.72 & -0.477 & $(0.147)^{* * *}$ & 1.38 & 1.14 & -0.239 & $(0.134)^{*}$ \\
\hline Watching TV & 1.41 & 1.43 & 0.013 & $(0.065)$ & 1.20 & 1.19 & -0.008 & $(0.054)$ & 0.21 & 0.23 & 0.021 & $(0.048)$ \\
\hline Gaming & 1.97 & 0.98 & -0.987 & $(0.090) * * *$ & 1.34 & 0.73 & -0.611 & $(0.060) * * *$ & 0.63 & 0.25 & -0.376 & $(0.062)^{* * *}$ \\
\hline Social media & 1.19 & 1.44 & 0.254 & $(0.091)^{* * * *}$ & 0.87 & 1.03 & 0.162 & $(0.062)^{* * *}$ & 0.32 & 0.41 & 0.092 & $(0.061)$ \\
\hline Online media & 1.00 & 1.00 & 0.004 & $(0.063)$ & 0.78 & 0.76 & -0.020 & $(0.044)$ & 0.22 & 0.24 & 0.024 & $(0.051)$ \\
\hline
\end{tabular}

Notes: Average hours spent on different activities on a typical workday. During Corona: period of school closures due to COVID-19. Before Corona: period before the school closures. Low-ed: parents without a university degree. High-ed: parents with a university degree. Std. err.: standard errors stemming from regressions of hours spent on each activity on a high-ed and female indicator, respectively. Significance levels: $* * * p<0.01, * * \mathrm{p}<0.5$, * $\mathrm{p}<0.1$. Data source: ifo Education Survey 2020. 
schools were not able to compensate for the adverse effects of the closures on educational inequality. To the contrary, those students more in need of additional support to keep up learning during the school closures were less likely to benefit from distance-teaching activities. $^{26}$

\section{Other dimensions of inequality}

This section investigates whether the school closures also amplified educational inequality along other dimensions than students' prior achievement, namely parents' educational background (Section 6.1) and students' gender and school type (Section 6.2).

\subsection{Differences by parents' educational background}

In the public debate, there is concern that the COVID-19-induced school closures could aggravate educational inequality between children from different socioeconomic backgrounds (e.g., UNESCO 2020b; European Commission, 2020). Family background has been shown to strongly impact students' educational success (e.g., Björklund and Salvanes 2011).

While children of university-educated parents invested more time in out-of-school learning activities before COVID-19 than children of parents without a university degree, the reduction in learning time during the school closures did not differ significantly between children of parents with $\left(-3.7 \mathrm{~h}\right.$ per day) or without $(-3.8 \mathrm{~h})$ a university degree (upper panel of Table 5 ). ${ }^{27}$ While children of university-educated parents spent marginally significantly more time on school-related activities during the closures (3.8 versus 3.55 h), most of this gap already existed before COVID-19. ${ }^{28}$ Children of university-educated parents did increase their time on other conducive activities more. They also spent less time on detrimental activities both before and during the closures, but the change over time was not significantly different from children of parents without a university degree.

At the same time, there are strong differences in school support during the closures by family background. For instance, children without university-educated parents were 12 percentage points less likely than children with university-educated parents to be taught in online lessons more than once a week, and 15 percentage points less likely to have individual contact with their teachers more than once a week (not shown). This pattern raises concerns that the school closures might have exacerbated inequality in student achievement by children's socioeconomic background, even though the learning-time gap did not widen.

\subsection{Differences by students' gender and school type}

Analysis by student gender indicates that the school closures reduced boys' learning time more than girls'. Before the closures, there was no significant gender difference in learning time (lower panel of Table 5). By contrast, boys spent half an hour less than girls learning at home during the school closures ( 3.4 versus $3.9 \mathrm{~h}, p<0.01$ ). Boys substituted learning time mostly for playing computer games, whereas girls mostly increased their time on social media, reinforcing gender differences in both dimensions. The overall gender effect of the closures may exacerbate the "boy crisis" in education (e.g., Cappelen et al., 2019).

There are also noteworthy differences between students in primary, upper-track secondary (Gymnasium), and other secondary school. During Corona, primary-school students were more likely to attend emergency services in schools, which were open only to younger children (Appendix Table A8). Upper-track secondary-school students spent more time learning at home (3.2 h) than their lower-track and primary-school counterparts ( $2.5 \mathrm{~h}$ each). Still, in absolute terms, both types of secondary-school students lost learning time to a similar extent. Primary-school students expanded other conducive activities - in particular, physical exercise - more than secondary-school students, who mostly expanded gaming and social media.

\section{Discussion}

The detailed time-use survey data provide novel and otherwise unavailable information on students' learning during the COVID19-induced school closures. Still, several points should be kept in mind in interpreting the findings. First, students' time spent on learning and other activities are imperfect proxies for how much they actually learn (e.g., Hanushek and Woessmann 2008). Arguably, high-achieving students are more effective in turning learning time into knowledge and skills (see Section 2.1). In this case, our results

\footnotetext{
${ }^{26}$ Consistently, the share of parents reporting to be satisfied with their school's activities during the school closures was 13 percentage points lower for low- than for high-achieving students (Appendix Table Tables A7).

${ }^{27}$ Consistently, learning time during the school closures also did not differ between students with above and below median household income. Due to longer school attendance before the closures, the decline was actually larger for students from high-income households (results available upon request).

${ }^{28}$ We find the same qualitative pattern of results when using a more fine-grained categorization of parental education (no degree, vocational degree, advanced vocational degree (e.g., Meister), and university degree). Detailed results are available upon request.
} 
likely constitute a lower bound for the impact of school closures on skill inequality by student's prior achievement. ${ }^{29}$

Second, survey responses could be subject to social-desirability bias. For instance, parents may inflate reported learning time because they think it is considered socially appropriate. However, research shows that social desirability does not yield major bias in anonymous online surveys as ours (e.g., Das and Laumann 2010). In fact, parents reported that during the closures, their child spent much more time on detrimental activities such as watching TV or computer gaming than on learning. This pattern is inconsistent with a major influence of social-desirability bias on answering behavior. Furthermore, any remaining bias would imply that the large discrepancy between school-related and detrimental activities found in our data even underestimates the true difference.

Third, our analyses are partly based on retrospective reports on how much time children spent on different activities before the school closures. While we cannot rule out that selective memory leads to measurement error in the data (e.g., Zimmermann 2020), it is reassuring that the retrospective answers are plausible in the sense that reported hours spent in school before the closures correspond closely to the hours prescribed in the school curricula. Furthermore, our retrospective data closely resemble students' self-reported learning time elicited in the 2018 wave of the German Socio-Economic Panel Study (GSOEP), which further raises confidence in the validity of our retrospective time-use data. ${ }^{30}$

Fourth, the survey data could suffer from measurement error because parents do not know exactly how much time their child spends on different activities. However, only $21 \%$ of respondents state that both they and their partner worked at least half a day outside the home during the school closures. The relatively intense parent-child contact in most households increases parents' ability to monitor their child's activities, so that most parents should be able to assess these activities reasonably well. Reassuringly, a survey of students in the final two grades of upper-track secondary school in eight German states by Anger et al. (2020) also finds that learning time during the school closures differs markedly by students' previous school grades, but not by parental educational background. This indicates that our results are unlikely driven by measurement error from lacking knowledge of parents in our data.

Fifth, survey fatigue can lead to respondents not answering some questions conscientiously. However, 500 of the 1099 parents in our sample used the provided open answer field to type in "another activity" in the time-use battery, which indicates that they were very conscientious in filling out the survey.

Finally, the extent to which our results for Germany are informative for other contexts is ultimately an empirical question that we cannot answer with our data. On the one hand, most countries were at least as affected by the COVID-19 pandemic as Germany, had broadly similar school-closure policies, had no previous experience with nation-wide school closures, and had no concepts in place for online school operations. Reports from many countries indicate that the organization of distance-teaching activities was challenging and caused major problems not only in Germany (e.g., Andrew et al. 2020, Chetty et al. 2020, Engzell et al. 2021 and Maldonado and Witte 2020). On the other hand, there is some indication that Germany lagged other countries in the classroom usage of digital technologies before the pandemic (e.g., Beblavý et al. 2019 and Fraillon et al. 2020), raising the possibility that some other countries may have fared better in providing online teaching for their students and particularly support the low-achievers.

\section{Conclusion}

We present novel time-use data on the activities of more than 1000 school children before and during the COVID-19 school closures in Germany. On average, the school closures reduced students' learning time by about half. This reduction was significantly larger for low-achieving than for high-achieving students. Especially low-achieving students substituted the learning time for detrimental activities such as watching TV and playing computer games, rather than for conducive activities. Neither parents nor schools compensated for the increased learning gap by students' prior achievement and actually provided less support for low- than for highachieving students. The reduction in students' learning time did not vary by parents' educational background (though children without university-educated parents received less school support during the closures), but it was larger for boys than for girls.

From a policy perspective, our results call for universal and binding distance-teaching concepts for school closures that are particularly geared towards low-achieving students. Leaving the decision over whether and how to maintain teaching operations during school closures at schools' or teachers' discretion has proven largely unsuccessful in our setting. In fact, proposals to instruct teachers to maintain daily contact with their students, require all schools to switch to online teaching if in-person classes are not possible, and enable online teaching by compulsory teacher training and providing digital equipment to students who cannot afford them have overwhelming majority appeal in the German electorate (Woessmann et al., 2020). Our results suggest that it is particularly the low-achieving students who suffer when support of teachers is lacking, so that any attempt to support their learning when schools have to close is likely to reduce future educational inequality.

\footnotetext{
${ }^{29}$ In addition, an interesting interpretative question that remains unanswered from our analysis is what exact subjects were taught and at what intensity during the school closures. While some evidence speaks against a strong shift in teaching emphasis to core subjects such as mathematics or German (e.g., because teachers of all subjects were expected to engage in distance-teaching activities and because the majority of parents thinks their child learned "much less" than usual during the school closures), an in-depth analysis of distance-teaching curricula would be interesting for future research.

${ }^{30}$ The GSOEP asks 12-15-year-olds: "How much time do you usually spend on homework and studying for school?" Answer categories are less than half an hour a day, half an hour to less than $1 \mathrm{~h}$ a day, 1 to less than $2 \mathrm{~h}$ a day, 2 to less than $3 \mathrm{~h}$ a day, 3 to less than $4 \mathrm{~h}$ a day, and $4 \mathrm{~h}$ and more a day. The average answer is $1.1 \mathrm{~h}$ of daily learning for school, compared to $1.5 \mathrm{~h}$ that parents of children in the same age range report in our sample. Importantly, the GSOEP data reveals no difference in learning time between low- and high-achieving students (using our grade-based classification), which is also in line with our results.
} 


\section{Appendix A. Additional Figures and Tables}

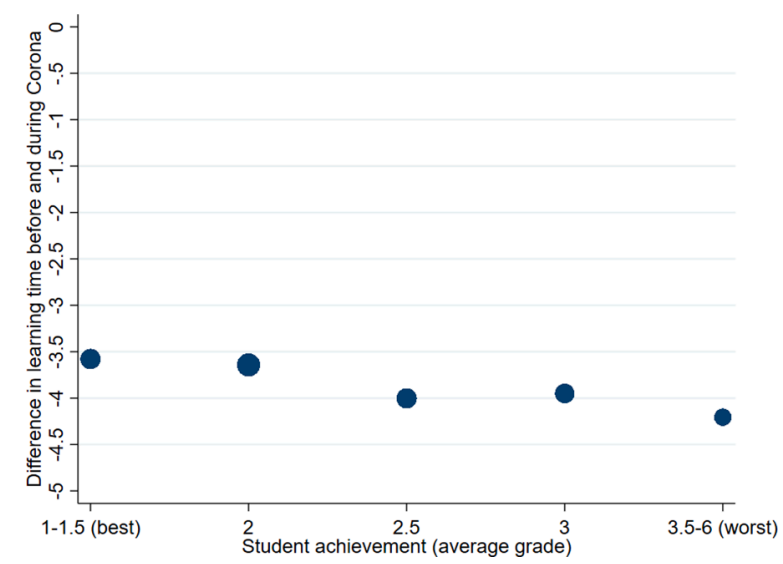

Fig. A1. Reduction in learning time by student achievement

Notes: Difference in average hours spent on school activities on a typical workday between the period before the school closures and the period of school closures due to COVID-19. Student achievement (average grade): average of school grade in mathematics and German. Size of markers indicates number of observations. Average grades range from 1 (best grade) to 6 (worst grade). To ensure sufficient size of each category, observations are grouped as follows: grade 1.5 or better ( 20 percent of the sample), grade 2 ( 28 percent), grade 2.5 ( 20 percent), grade 3 (18 percent), and grade 3.5 or worse (14 percent). Data source: ifo Education Survey 2020.

Table A1

Timing of school re-openings by state and class type.

\begin{tabular}{|c|c|c|c|c|c|c|}
\hline \multirow[b]{2}{*}{ State } & \multicolumn{2}{|c|}{$\begin{array}{l}\text { Transfer classes (in final year of primary } \\
\text { school) }\end{array}$} & \multicolumn{2}{|c|}{ Graduation classes } & \multicolumn{2}{|l|}{ All other classes } \\
\hline & Re-opening date & School operations & Re-opening date & School operations & Re-opening date & School operations \\
\hline Baden-Württemberg & 18 May 2020 & partial & 4. May 2020 & partial & 15 June 2020 & partial \\
\hline Bavaria & 11 May 2020 & partial & 27 April 2020 & partial & 15 June 2020 & partial \\
\hline Berlin & 4 May 2020 & partial & 20 April 2020 & partial & 1 June 2020 & partial \\
\hline Brandenburg & 4 May 2020 & partial & 27 April 2020 & partial & 25 May 2020 & partial \\
\hline Bremen & 4 May 2020 & partial & 27 April 2020 & partial & 15 June 2020 & partial \\
\hline Hamburg & 4 May 2020 & partial & 27 April 2020 & partial & 1 June 2020 & partial \\
\hline Hesse & 18 May 2020 & partial & 27 April 2020 & partial & 2 June 2020 & partial \\
\hline Lower Saxony & 4 May 2020 & partial & 27 April 2020 & partial & 15 June 2020 & partial \\
\hline Mecklenburg-West Pomerania & 4 May 2020 & partial & 27 April 2020 & partial & 1 June 2020 & partial \\
\hline North Rhine-Westphalia & 7 May 2020 & partial & 20 April 2020 & partial & 2 June 2020 & partial \\
\hline Rhineland-Palatine & 25 May 2020 & partial & 25 May 2020 & partial & 8 June 2020 & partial \\
\hline Saarland & 4 May 2020 & partial & 4 May 2020 & partial & 8 June 2020 & partial \\
\hline Saxony & 6 May 2020 & full & 6 May 2020 & partial & 18 June 2020 & partial \\
\hline Saxony-Anhalt & 4 May 2020 & partial & 4 May 2020 & partial & 15 June 2020 & partial \\
\hline Schleswig-Holstein & 6 May 2020 & partial & 27 April 2020 & partial & 1 June 2020 & partial \\
\hline Thuringia & 11 May 2020 & partial & 4 May 2020 & partial & 2 June 2020 & partial \\
\hline
\end{tabular}

Notes: Transfer classes (Übertrittsklassen) are in the last year of primary school, which in most states corresponds to grade 4. Graduation classes end secondary school in that year (which can be grade 9, 10,12, or 13, depending on the type of school). The re-opening dates for all other classes refer to the date when all classes had the opportunity to return to school. "Partial" school operations mean that not all students in the respective classes were in school at the same time, but - in accordance with school-specific rules - were in school part of the time and otherwise at home. Source: https:// deutsches-schulportal.de/bildungswesen/schuloeffnung-das-haben-die-laenderchefs-entschieden/ [access June 7, 2021]. 
Table A2

Comparison of analysis sample to Microcensus data

\begin{tabular}{|c|c|c|}
\hline & $\begin{array}{l}\text { Microcensus } \\
\text { (1) }\end{array}$ & $\begin{array}{l}\text { Analysis sample } \\
\text { (2) }\end{array}$ \\
\hline \multicolumn{3}{|l|}{ Child characteristics } \\
\hline \multicolumn{3}{|l|}{ School type } \\
\hline Primary school & $0.335(0.002)$ & $0.361(0.014)$ \\
\hline Upper-track secondary school (Gymnasium) & $0.301(0.002)$ & $0.301(0.014)$ \\
\hline Other secondary school & $0.364(0.002)$ & $0.338(0.014)$ \\
\hline Age & $12.07(0.016)$ & $12.48(0.106)$ \\
\hline Girl & $0.491(0.002)$ & $0.483(0.015)$ \\
\hline Living with both parents & $0.783(0.002)$ & $0.800(0.012)$ \\
\hline \multicolumn{3}{|l|}{ Parent characteristics } \\
\hline \multicolumn{3}{|l|}{ Educational attainment } \\
\hline Mother with (Fach-)Abitur & $0.362(0.002)$ & $0.437(0.021)$ \\
\hline Father with (Fach-)Abitur & $0.410(0.003)$ & $0.474(0.021)$ \\
\hline \multicolumn{3}{|l|}{ Working status } \\
\hline Mother works full-time & $0.211(0.002)$ & $0.233(0.013)$ \\
\hline Father works full-time & $0.876(0.002)$ & $0.671(0.015)$ \\
\hline West Germany & $0.832(0.002)$ & $0.795(0.012)$ \\
\hline Observations & 49,621 & 1,099 \\
\hline
\end{tabular}

Notes: Means; standard errors in parentheses. Column (1): all children aged below 20 years in general schools in the Microcensus 2015 (representative of the German population). Column (2): our analysis sample, referring to youngest school-aged child of parents in our survey data. Data sources: Microcensus 2015 and ifo Education Survey 2020.

Table A3

Sample characteristics

\begin{tabular}{|c|c|c|c|}
\hline & \multirow{2}{*}{$\begin{array}{l}\text { Sample means } \\
\text { (1) }\end{array}$} & \multicolumn{2}{|c|}{ Regression of high-achiever indicator on sample characteristics } \\
\hline & & $\begin{array}{l}\text { Coef. } \\
(2)\end{array}$ & $\begin{array}{l}\text { Std. err. } \\
\text { (3) }\end{array}$ \\
\hline \multicolumn{4}{|l|}{ Child characteristics } \\
\hline \multicolumn{4}{|l|}{ School type } \\
\hline Elementary school & 0.361 & & \\
\hline Upper-track secondary school (Gymnasium) & 0.301 & -0.001 & $(0.054)$ \\
\hline Other secondary school & 0.338 & 0.033 & $(0.049)$ \\
\hline Age & 12.48 & -0.024 & $(0.007)^{* * *}$ \\
\hline Girl & 0.484 & 0.038 & $(0.031)$ \\
\hline Single child & 0.383 & -0.010 & $(0.033)$ \\
\hline \multicolumn{4}{|l|}{ Parent characteristics } \\
\hline Female & 0.490 & -0.047 & $(0.034)$ \\
\hline University degree & 0.273 & 0.015 & $(0.040)$ \\
\hline Single parent & 0.155 & 0.026 & $(0.047)$ \\
\hline Child not in household & 0.080 & -0.109 & $(0.060) *$ \\
\hline Parent in home office ${ }^{+}$ & 0.342 & 0.105 & $(0.037)^{* * *}$ \\
\hline Work hours & 23.20 & 0.000 & $(0.001)$ \\
\hline Partner at home $\mathrm{e}^{++}$ & 0.185 & 0.020 & $(0.042)$ \\
\hline Household income & 3370.4 & 0.002 & $(0.001)$ \\
\hline West Germany & 0.795 & -0.063 & $(0.039)$ \\
\hline Observations & 1,099 & 978 & \\
\hline$R^{2}$ & & 0.059 & \\
\hline
\end{tabular}

Notes: Column (1): sample means. Columns (2)-(3): dependent variable: dummy for high-achieving student (average grade in mathematics and German at or above the median for respective school type). In the regression, work hours and household income are divided by 100 . Significance levels: ${ }^{* * *} p<0.01,{ }^{* *} p<0.5, * p<0.1$. Data source: ifo Education Survey $2020{ }^{+}$Parent in home office: responding parent reports a positive number of hours working from home during the period of school closures. ${ }^{++}$Partner at home: dummy $=1$ if additional adult in household who works less than 20 hours per week during period of school closures, 0 otherwise. 
Table A4

Parental assessment of whether activities are beneficial for child development

\begin{tabular}{|c|c|c|c|c|c|c|c|}
\hline & \multirow[b]{2}{*}{$\begin{array}{l}\text { Average } \\
\text { (1) }\end{array}$} & \multirow[b]{2}{*}{$\begin{array}{l}\text { Low-achievers } \\
\text { (2) }\end{array}$} & \multirow[b]{2}{*}{$\begin{array}{l}\text { High-achievers } \\
\text { (3) }\end{array}$} & \multicolumn{2}{|c|}{ Unconditional gap } & \multicolumn{2}{|c|}{ Conditional gap } \\
\hline & & & & $\begin{array}{l}\text { Gap } \\
(4)\end{array}$ & $\begin{array}{l}\text { Std. err. } \\
\text { (5) }\end{array}$ & $\begin{array}{l}\text { Gap } \\
\text { (6) }\end{array}$ & $\begin{array}{l}\text { Std. err. } \\
\text { (7) }\end{array}$ \\
\hline Attending school & 0.97 & 0.96 & 0.97 & 0.006 & $(0.012)$ & -0.000 & $(0.012)$ \\
\hline Learning for school & 0.93 & 0.91 & 0.95 & 0.034 & $(0.016)^{* *}$ & 0.032 & $(0.017)^{*}$ \\
\hline Reading & 0.89 & 0.83 & 0.91 & 0.077 & $(0.021)^{* * *}$ & 0.074 & $(0.022)^{* * *}$ \\
\hline Music and creative work & 0.82 & 0.78 & 0.82 & 0.039 & $(0.025)$ & 0.029 & $(0.027)$ \\
\hline Physical exercise & 0.95 & 0.94 & 0.95 & 0.009 & $(0.015)$ & 0.015 & $(0.015)$ \\
\hline Watching TV & 0.30 & 0.27 & 0.35 & 0.083 & $(0.030)^{* * *}$ & 0.066 & $(0.031)^{* *}$ \\
\hline Gaming & 0.22 & 0.19 & 0.25 & 0.060 & $(0.026)^{* *}$ & 0.055 & $(0.028)^{* *}$ \\
\hline Social media & 0.24 & 0.23 & 0.27 & 0.036 & $(0.028)$ & 0.029 & $(0.030)$ \\
\hline Online media & 0.34 & 0.33 & 0.39 & 0.063 & $(0.031)^{* *}$ & 0.048 & $(0.033)$ \\
\hline
\end{tabular}

Notes: Dummy=1 for respondents who say activity is "very beneficial" or "rather beneficial" for the further development of their child (on a five-point scale from "not beneficial at all" to "very beneficial"). Low- versus high-achievers: students with an average grade in mathematics and German below versus at-or-above the median for their respective school type. Std. err.: reports standard errors of regression from dummy $=1$ for high-achievers on hours in each category. Conditional gap: see Table 2 for controls. Significance levels: ${ }^{* * *} p<0.01,{ }^{* *} p<0.5,{ }^{*} p<0.1$. Data source: ifo Education Survey 2020 .

Table A5

Average student activities before and during the school closures

\begin{tabular}{llll}
\hline & $\begin{array}{l}\text { During Corona } \\
(1)\end{array}$ & $\begin{array}{l}\text { Before Corona } \\
(2)\end{array}$ & $\begin{array}{l}\text { Difference } \\
(3)\end{array}$ \\
\hline School activities & & & 7.42 \\
Aggregate & 3.62 & 5.92 & -3.80 \\
$\quad$ Attending school & 0.90 & 1.51 & 1.01 \\
$\quad$ Learning for school & 2.72 & & \\
Conducive activities & & 2.89 & 0.31 \\
Aggregate & 3.20 & 0.67 & 0.10 \\
$\quad$ Reading & 0.77 & 0.61 & 0.16 \\
$\quad$ Music and creative work & 0.77 & 1.62 & 0.05 \\
$\quad$ Physical exercise & 1.67 & 3.96 & 1.26 \\
Detrimental activities & & 1.20 & 0.22 \\
Aggregate & 5.22 & 1.04 & 0.45 \\
$\quad$ Watching TV & 1.42 & 0.95 & 0.36 \\
$\quad$ Gaming & 1.49 & 0.77 & 0.23 \\
$\quad$ Social media & 1.31 & \\
$\quad$ Online media & 1.00 & & \\
\hline
\end{tabular}

Notes: Average hours spent on different activities on a typical workday. During Corona: period of school closures due to COVID-19. Before Corona: period before the school closures. Data source: ifo Education Survey 2020.

Table A6

Distribution of school-related activities during the school closures.

\begin{tabular}{llllllllll}
\hline & $\begin{array}{l}\text { At most ... } \\
\text { 0 hours } \\
(1)\end{array}$ & $\begin{array}{l}1 \text { hour } \\
(2)\end{array}$ & $\begin{array}{l}2 \text { hours } \\
(3)\end{array}$ & $\begin{array}{l}3 \text { hours } \\
(4)\end{array}$ & $\begin{array}{l}4 \text { hours } \\
(5)\end{array}$ & $\begin{array}{l}5 \text { hours } \\
(6)\end{array}$ & $\begin{array}{l}6 \text { hours } \\
(7)\end{array}$ & $\begin{array}{l}7 \text { hours } \\
(8)\end{array}$ & $\begin{array}{l}8 \text { hours } \\
(9)\end{array}$ \\
\hline All & 0.023 & 0.144 & 0.378 & 0.568 & 0.742 & 0.818 & 0.881 & 0.918 \\
Low-achievers & 0.030 & 0.188 & 0.435 & 0.613 & 0.783 & 0.849 & 0.902 & 0.936 \\
High-achievers & 0.015 & 0.104 & 0.326 & 0.516 & 0.701 & 0.791 & 0.872 & 0.910 & 0.961 \\
\hline
\end{tabular}

Notes: Hours spent on "attending school" or "learning for school" on a typical workday during the period of school closures due to COVID-19. Lowversus high-achievers: students with an average grade in mathematics and German below versus at-or-above the median for their respective school type. Data source: ifo Education Survey 2020. 
Table A7

Parental assessment of home environment and child's learning

\begin{tabular}{|c|c|c|c|c|c|c|c|}
\hline & \multirow[b]{2}{*}{$\begin{array}{l}\text { Average } \\
\text { (1) }\end{array}$} & \multirow[b]{2}{*}{$\begin{array}{l}\text { Low-achievers } \\
\text { (2) }\end{array}$} & \multirow[b]{2}{*}{$\begin{array}{l}\text { High-achievers } \\
\text { (3) }\end{array}$} & \multicolumn{2}{|c|}{ Unconditional gap } & \multicolumn{2}{|c|}{ Conditional gap } \\
\hline & & & & $\begin{array}{l}\text { Gap } \\
\text { (4) }\end{array}$ & $\begin{array}{l}\text { Std. err. } \\
\text { (5) }\end{array}$ & $\begin{array}{l}\text { Gap } \\
(6)\end{array}$ & $\begin{array}{l}\text { Std. err. } \\
\text { (7) }\end{array}$ \\
\hline Family coped well & 0.87 & 0.85 & 0.90 & 0.049 & $(0.021)^{* * *}$ & 0.060 & $(0.022)^{* * *}$ \\
\hline Psychological burden for child & 0.38 & 0.39 & 0.36 & -0.030 & $(0.031)$ & -0.060 & $(0.033) *$ \\
\hline Psychological burden for parent & 0.38 & 0.37 & 0.34 & -0.028 & $(0.031)$ & -0.046 & $(0.032)$ \\
\hline Argued more with child & 0.28 & 0.30 & 0.24 & -0.055 & $(0.028)^{*}$ & -0.080 & $(0.030)^{* * *}$ \\
\hline Assessment of home learning environment & 3.86 & 3.70 & 4.01 & 0.312 & $(0.063)^{* * *}$ & 0.289 & $(0.067)^{* * *}$ \\
\hline Satisfied with school activities & 0.57 & 0.49 & 0.62 & 0.131 & $(0.032)^{* * *}$ & 0.113 & $(0.034)^{* * *}$ \\
\hline Child learned much less & 0.64 & 0.72 & 0.58 & -0.142 & $(0.031)^{* * *}$ & -0.135 & $(0.032)^{* * *}$ \\
\hline
\end{tabular}

Notes: Rows 1-4 and 7: probability that statement "fully applies" or "rather applies" (on a five-point scale from "does not apply at all" to "fully applies"); question wording: "Our family coped well with the situation during the school closures."; "The phase of school closures was a great psychological burden for my child/for me."; "I argued with my child during the school closures more than usual."; "My child has learned much less during the school closures than usual in school." Row 5: average grade provided on 5-point scale (1="insufficient", $5=$ "very good"); question wording: "How would you evaluate your child's learning environment at home during the period of several weeks of Corona-related school closure, e. g., in terms of available computers or space to work?" Row 6: probability that respondents are "very satisfied" or "satisfied" (on a five-point scale from "very unsatisfied" to "very satisfied"); question wording: "Overall, how satisfied are you with the activities your child's school carried out during the several weeks of Corona-related school closure?" Low- versus high-achievers: students with an average grade in mathematics and German below versus at-or-above the median for their respective school type. Std. err.: standard errors stemming from regressions of the respective outcome variable on a high-achiever indicator. Conditional gap: see Table 2 for controls. Significance levels: ${ }^{* *} p<0.01$, ${ }^{* *} p<0.5$, ${ }^{*} p<0.1$. Data source: ifo Education Survey 2020.

Table A8

Student activities before and during the school closures by school type

\begin{tabular}{|c|c|c|c|c|c|c|c|c|c|}
\hline & \multicolumn{3}{|c|}{ During Corona } & \multicolumn{3}{|c|}{ Before Corona } & \multicolumn{3}{|c|}{ Difference during-before } \\
\hline & $\begin{array}{l}\text { Primary } \\
\text { (1) }\end{array}$ & $\begin{array}{l}\text { Secondary } \\
\text { Upper-track } \\
\text { (2) }\end{array}$ & $\begin{array}{l}\text { Other } \\
\text { (3) }\end{array}$ & $\begin{array}{l}\text { Primary } \\
\text { (4) }\end{array}$ & $\begin{array}{l}\text { Secondary } \\
\text { Upper-track } \\
\text { (5) }\end{array}$ & $\begin{array}{l}\text { Other } \\
\text { (6) }\end{array}$ & $\begin{array}{l}\text { Primary } \\
\text { (7) }\end{array}$ & $\begin{array}{l}\text { Secondary } \\
\text { Upper-track } \\
\text { (8) }\end{array}$ & $\begin{array}{l}\text { Other } \\
\text { (9) }\end{array}$ \\
\hline \multicolumn{10}{|l|}{ School activities } \\
\hline Aggregate & 3.62 & 3.91 & 3.37 & 6.98 & 7.97 & 7.40 & -3.36 & -4.06 & -4.03 \\
\hline Attending school & 1.08 & 0.75 & 0.85 & 5.63 & 6.17 & 5.99 & -4.55 & -5.42 & -5.14 \\
\hline Learning for school & 2.54 & 3.16 & 2.52 & 1.35 & 1.80 & 1.41 & 1.19 & 1.36 & 1.11 \\
\hline \multicolumn{10}{|l|}{ Conducive activities } \\
\hline Aggregate & 3.89 & 2.84 & 2.79 & 3.41 & 2.50 & 2.69 & 0.48 & 0.34 & 0.09 \\
\hline Reading & 0.93 & 0.74 & 0.62 & 0.82 & 0.56 & 0.59 & 0.10 & 0.18 & 0.03 \\
\hline Music and creative work & 0.93 & 0.75 & 0.61 & 0.76 & 0.53 & 0.53 & 0.17 & 0.23 & 0.08 \\
\hline Physical exercise & 2.03 & 1.35 & 1.56 & 1.83 & 1.41 & 1.57 & 0.21 & -0.06 & -0.02 \\
\hline \multicolumn{10}{|l|}{ Detrimental activities } \\
\hline Aggregate & 3.71 & 5.85 & 6.29 & 2.90 & 4.17 & 4.92 & 0.81 & 1.68 & 1.37 \\
\hline Watching TV & 1.37 & 1.45 & 1.45 & 1.16 & 1.14 & 1.28 & 0.21 & 0.31 & 0.17 \\
\hline Gaming & 1.11 & 1.48 & 1.91 & 0.83 & 0.94 & 1.37 & 0.28 & 0.54 & 0.55 \\
\hline Social media & 0.54 & 1.73 & 1.76 & 0.39 & 1.21 & 1.32 & 0.15 & 0.52 & 0.44 \\
\hline Online media & 0.69 & 1.19 & 1.16 & 0.52 & 0.87 & 0.95 & 0.17 & 0.32 & 0.21 \\
\hline
\end{tabular}

Notes: Average hours spent on different activities on a typical workday. During Corona: period of school closures due to COVID-19. Before Corona: period before the school closures. Primary: students in primary school. Upper-track: students in upper-track secondary school (Gymnasium). Other: students in other secondary school. Data source: ifo Education Survey 2020.

\section{Appendix B. General Overview of the German School System}

To provide context for the presented results, this appendix briefly presents some stylized facts about the German school system.

Germany's education system is decentralized, with each of the 16 states holding legislative and executive power over their respective school system. Although there are some differences between states, the general structure of the school system is similar across states. In general, enrollment in primary school is based on the catchment area in which a child lives. Generally based on their achievement in the fourth and final grade of primary school, children are usually sorted into one of two or three secondary-school tracks at age ten. The exact designations vary from state to state, but the possible tracks typically include a basic track (five or six years), a middle track (six years), and a high track (eight or nine years). The high track leads to the university entrance qualification (Abitur). Only a small share of 11 percent of schools in Germany are private schools (Destatis 2020), and many of these schools have ecclesiastic operators.

Educational inequality in Germany is quite high. For example, comparing PISA test scores of 15-year-olds in mathematics, students from families with low socioeconomic status (defined as being in the lowest decile of the PISA Index of Economic, Social and Cultural 
Status) lag behind their high-SES peers (top decile) by a test-score difference equivalent to four years of schooling (Lergetporer, Werner, and Woessmann, 2020). Differences in PISA test scores by students' socioeconomic background in Germany are the third largest among all OECD countries (OECD (2020)).

Another feature that is particularly relevant in the context of the COVID-19-induced school closures is the poor digitization of schools in Germany. For example, Beblavý et al. (2019) compare all EU-27 countries and find that Germany ranks last in terms of digital learning. The authors conclude that this finding is not very surprising as "Germany has come under scrutiny for under-investment in digital infrastructure, low internet connection speeds, and a lack of broadband access throughout its territory" (Beblavý et al. 2019, p. 23).

\section{Supplementary materials}

Supplementary material associated with this article can be found, in the online version, at doi:10.1016/j.euroecorev.2021.103920.

\section{References}

Alon, T., Doepke, M., Olmstead-Rumsey, J., Tertilt, M., 2020. The Impact of COVID-19 on Gender Equality. National Bureau of Economic Research, Cambridge, MA. NBER Working Paper No. 26947.

Andrew, A., Cattan, S., Dias, M.C., Farquharson, C., Kraftman, L., Krutikova, S., Phimister, A., Sevilla, A., 2020. Inequalities in Children's Experiences of Home Learning during the COVID-19 Lockdown in England. Fisc. Stud. 41 (3), 653-683.

Anger, S., Dietrich, H., Patzina, A., Sandner, M., Lerche, A., Bernhard, S., Toussaint, C., 2020. School Closings During the COVID-19 Pandemic: Findings from German High School Students. Institute for Employment Research of the Federal Employment Agency. IAB-Forum. Nuremberg.

Bacher-Hicks, A., Goodman, J., Mulhern, C., 2021. Inequality in household adaptation to schooling shocks: COVID-induced online learning engagement in real time. J. Public Econ. 193, 104345.

Beblavý, M., Baiocco, S., Kilhoffer, Z., Akgüç, M., Jacquot, M. (2019). Index of Readiness for Digital Lifelong Learning: Changing How Europeans Upgrade their Skills. CEPS Final Report. Brussels: Centre for European Policy Studies in partnership with Grow with Google.

Björklund, A., Salvanes, K.G., 2011. Education and family background: mechanisms and policies. Handbook of the Economics of Education, Vol. 3, edited by Eric A. Hanushek, Stephen Machin, Ludger Woessmann. Amsterdam: North Holland, pp. 201-247.

Cappelen, A.W., Falch, R., Tungodden, B. (2019). The boy crisis: experimental evidence on the acceptance of males falling behind. Discussion Paper SAM 06/2019.

Chetty, R., JN. Friedman, N. Hendren, M. Stepner, Opportunity Insights Team (2020). How Did COVID-19 and stabilization policies affect spending and employment? A new real-time economic tracker based on private sector data. NBER Working Paper 27431. Cambridge, MA: National Bureau of Economic Research.

Chetty, R., Friedman, J.N., Rockoff, J.E., 2014. Measuring the impacts of teachers II: teacher value-added and student outcomes in adulthood. Am. Econ. Rev. 104 (9), 2633-2679.

Cunha, F., Heckman, J.J., 2007. The technology of skill formation. Am. Econ. Rev. 97 (2), 31-47.

Cunha, F., Heckman, J.J., Lochner, L., Masterov, D.V., 2006. Interpreting the evidence on life cycle skill formation. Handbook of the Economics of Education, Vol. 1, edited by Eric A. Hanushek, Finis Welch. Amsterdam: North Holland, pp. 697-812.

Cunha, F., Heckman, J.J., Schennach, S.M., 2010. Estimating the technology of cognitive and noncognitive skill formation. Econometrica 78 (3), 883-931.

Das, A., Laumann, E.O., 2010. How to get valid answers from survey questions: what we learned from asking about sexual behavior and the measurement of sexuality. The Sage Handbook of Measurement, edited by Geoffrey Walford, Eric Tucker,Madhu Viswanathan. Sage Publications, Eric Tucker, Madhu Viswanathan. London, pp. 9-26.

Destatis, 2020. Privatschulen in Deutschland. Fakten und Hintergründe. Statistisches Bundesamt, Wiesbaden.

Engzell, P., Frey, A., Verhagen, M.D., 2021. Learning loss due to school closures during the COVID-19 pandemic. Proc. Natl. Acad. Sci. 118 (17), e2022376118.

European Commission, 2019. 2nd Survey of Schools: ICT in Education - Germany Country Report. European Commission, Luxembourg.

European Commission (2020). Educational inequalities in Europe and physical school closures during COVID-19. Fairness Policy Brief Series 04/2020.

Fetzer, T., Hensel, L., Hermle, J., Roth, C., 2020. Coronavirus perceptions and economic anxiety. Rev. Econ. Stat. In press.

Fiorini, M., Keane, M.P., 2014. How the allocation of Children's time affects cognitive and noncognitive development. J. Labor Econ. 32 (4), 787-836.

Fraillon, J., Ainley, J., Schulz, W., Friedman, T., Duckworth, D., 2020. Preparing For Life in a Digital World: IEA International Computer and Information Literacy Study 2018 International Report. International Association for the Evaluation of Educational Achievement (IEA), Amsterdam.

Hanushek, E.A., 1971. Teacher characteristics and gains in student achievement: estimation using micro data. Am. Econ. Rev. Pap. Proc. 61 (2), 280-288.

Hanushek, E.A., 1986. The economics of schooling: production and efficiency in public schools. J. Econ. Lit. 24 (3), $1141-1177$.

Hanushek, E.A., 2020. Education production functions. The Economics of Education: A Comprehensive Overview, edited by Steve Bradley, Colin Green, 2nd ed. Academic Press, London, pp. 161-170.

Hanushek, E.A., Woessmann, L., 2008. The role of cognitive skills in economic development. J. Econ. Lit. 46 (3), $607-668$.

Huber, S.G., Günther, P.S., Schneider, N., Helm, C., Schwander, M., Schneider, J.A., Pruitt, J., 2020. COVID-19 Und Aktuelle Herausforderungen in Schule und Bildung - Erste Befunde des Schul-Barometers in Deutschland, Österreich und Der Schweiz. Waxmann Verlag, Münster/New York.

Huber, S.G., Helm, C., 2020. COVID-19 and schooling: evaluation, assessment and accountability in times of crises - reacting quickly to explore key issues for policy, practice and research with the school barometer. Educ. Assess. Eval. Account. 32 (2), 237-270.

Lergetporer, P., Werner, K., Woessmann, L., 2020. Educational inequality and public policy preferences: evidence from representative survey experiments. J. Public Econ. 188, 104226.

Maldonado, E.J., Witte, K., 2020. The Effect of School Closures on Standardized Student Test Outcomes. Katholieke Universiteit, Leuven(KU) Leuven. Discussion Paper Series DPS20.17.

OECD (2020). Education GPS - Germany - student performance (PISA 2018). https://gpseducation.oecd.org/CountryProfile? primaryCountry=DEU\&treshold=10\&topic=PI[accessed June 8, 2021].

Robert Bosch Stiftung (2020). Das deutsche Schulbarometer Spezial - Lehrerbefragung zur Corona-Krise. https://deutsches-schulportal.de/unterricht/das-deutscheschulbarometer-spezial-corona-krise/ [accessed June 8, 2021].

Rivkin, S.G., Hanushek, E.A., Kain, J.F., 2005. Teachers, schools, and academic achievement. Econometrica 73 (2), 417-458. 
Schröder, M., Siegers, R., Spieß, C.K., 2013. Familien in Deutschland - FiD. Schmollers Jahrb. 133 (4), $595-606$.

UNESCO (2020). Education: from disruption to discovery. https://en.unesco.org/covid19/educationresponse [accessed July 25, 2020].

UNESCO (2020). Adverse consequences of school closures. https://en.unesco.org/covid19/educationresponse/consequences [accessed September 15, 2020].

Woessmann, L., 2020. Folgekosten ausbleibenden lernens: was wir über die corona-bedingten Schulschließungen aus der forschung lernen können. Ifo Schnelld. 73 (6), 38-44.

Woessmann, L., Freundl, V., Grewenig, E., Lergetporer, P., Werner, K., Zierow, L., 2020. Bildung in der corona-krise: wie haben die schulkinder die zeit der schulschließungen verbracht, UND welche Bildungsmaßnahmen befürworten die deutschen? Ifo Schnelld. 73 (9), 25-39.

Zimmermann, F., 2020. The dynamics of motivated beliefs. Am. Econ. Rev. 110 (2), 337-361. 